\title{
Atheneum Architektury XXI wieku. Rio de Janeiro
}

\section{Athenaeum of twenty-first-century archítecture: Rio de Janeiro}

\begin{abstract}
Streszczenie
Artykuł przedstawia efekt badań dotyczących potencjału współczesnego Rio de Janeiro jako miejsca dla projektu XXI wieku. Analiza architektury miasta w kontekście uwarunkowań społecznych, przestrzennych i przyrodniczych oraz analiza istniejących tam najważniejszych miejsc kulturotwórczych stały się punktem wyjścia do określenia ideowych wytycznych do projektu konkursowego Atheneum Architektury w Rio de Joneiro, który został przedstawiony w publikacji. Badania prowadzono w oparciu o metodę analizy krytycznej literatury oraz badania in citu.
\end{abstract}

\begin{abstract}
This paper presents the outcomes of a study on the potential of contemporary Rio de Janeiro to act as a site for a twenty-first century project. An analysis of the city's architecture in the context of social, spatial and wildlife-related determinants and an analysis of extant major culture-forming places became the starting point for determining conceptual guidelines for the competition design of the Architecture Athenaeum in Rio de Janeiro, which has been presented in the paper. The research was based on critical analysis of the literature and on-site studies.
\end{abstract}

Słowa kluczowe: Atheneum Architektury, Rio de Janeiro, XXI wiek

Keywords: Architecture Athenaeum, Rio de Janeiro, twenty-first century

\section{WSTĘP. CEL, ZAKRES, METODA}

Rio de Janeiro to miasto pełne kontrastów. Oszałamiająco piękna natura, zróżnicowanie kulturowo-etniczne mieszkańców, architektura wysokościowa, często bardzo nowoczesna stojąca w bezpośrednim sąsiedztwie faveli, ubóstwo, przestępczość i wszechobecna korupcja - to tylko niektóre z czynników wyróżniających Rio de Janeiro. Celem publikacji jest określenie potencjału miejsca pod kątem projektu Atheneum XXI wieku. ${ }^{1}$

Architektura o przeznaczeniu kulturowym lub edukacyjnym daje wyjątkowe możliwości pod względem kształtowania wizerunku przestrzennego danego miejsca oraz lokalnej tożsamości choćby poprzez aktywizację społeczności. Tego typu budynki mogą stać się miejscami symbolicznymi skupiającymi ludzi, którzy chcą tworzyć czy zmieniać świat na lepszy. Athenaeum, to historycznie miejsce skupiające ",światłe umysły". Jednak wraz z szybkimi zmianami, gwałtownym wzrostem populacji od początku XX w., nastaniem ery Internetu, możliwość pozytywnej ingerencji w otaczający świat $i$ jego problemy nie powinna być ograniczona do elit. Dlatego w ramach badań zrodziły się pytania: Czy w Rio de Janeiro istnieją obecnie miejsca ukształtowane do inspirowania, łączenia i skłaniania ludzi do refleksji? Czy istnieją obiekty poświęcone nauce, sztuce bądź kulturze, które poza samym udostępnianiem zbiorów wywołują interaktywność? Jeśli tak, w jaki sposób udaje im się to osiągnąć?

\section{INTRODUCTION}

Rio de Janeiro is a city of contrasts. Its astonishingly beautiful landscape, the cultural and ethnic diversity of its residents and high-rise, often highly modern architecture standing in close proximity to favelas, poverty, crime and ever-present corruption-are only some of factors that cause Rio de Janeiro to stand out. The objective of this paper is to identify place-based potential for the Twenty-first Century Athenaeum project. ${ }^{1}$

Cultural or educational architecture provides outstanding potential for shaping the spatial image of a given place and local identity, for instance by stimulating community activity. Such buildings can become symbolic places that are focal points for people who want to create or change the world for the better. The Athenaeum is a historical place that attracts 'bright minds'. However, along with rapid changes, the sudden population growth that has been ongoing since the start of the twentieth century or the coming of the era of the Internet, the potential for positive interventions in the surrounding world and its problems should not be confined to the elite. This is why a question arose during the research: does Rio de Janeiro currently has places designed to inspire, connect and make people more inclined towards reflection? Are there any buildings devoted to science, art or culture that, apart from providing access to their collections, induce interactivity? If so, then how do

\footnotetext{
* Prof. dr hab. inż. arch. Magdalena Jagiełło-Kowalczyk, Wydział Architektury Politechnika Krakowska / Prof. Ph.D. Eng. Arch. Magdalena Jagiełło-Kowalczyk, Faculty of Architecture, Cracow University of Technology, ORCID: 0000-0002-3971-839X, e-mail: magdajagiellok@interia.pl

** Dr. Associate Professor Stanislav Avsec, University of Ljubljana, Stanislav.Avsec@pef.uni-lj.si , ORCID: 0000-0002-0487-8115, e-mail: Stanislav.Avsec@pef.uni-lj.si 
Przedstawione w publikacji analizy mają na celu jak najlepsze zrozumienie ,klimatu socjologicznego" oraz historycznego jaki miał wpływ na obecną architekturę Rio de Janeiro. Wyniki badań są też punktem wyjścia do określenia wytycznych służących projektowi Athenaeum Architektury XXI wieku. Ma ono za zadanie nie tylko zapewnić możliwość zapoznania się z historią architektury w typowo muzealnym bądź książkowym stylu, ale być miejscem, które zaprosi do poznawania ewolucji architektury i tego czym ona jest w sposób niekoniecznie oczywisty, nowoczesny, interaktywny, zaskakujący, inspirujący.

\section{ATHENEUM}

Athenaeum to miejsce służące nauce bądź promocji nauki i kultury. ${ }^{2}{ }^{3}$ Często oznacza budynek, który zawiera w sobie bibliotekę i przestrzenie do czytania i nauki. Etymologia słowa Athenaeum prowadzi do pierwszego Athenaeum - szkoły Sztuk Pięknych w starożytnym Rzymie, która zawdzięcza swoją nazwę greckiemu słowu Athenaion, oznaczającemu świątynię Ateny, bogini mądrości. W starożytnej Grecji budynek o tej nazwie służył jako miejsce wykładów profesorów różnych dziedzin, a aktorzy lub poeci mogli przygotowywać się do występów lub tworzyć dzieła. Swoje obecne przeznaczenie, jako miejsca związanego z szeroko pojętą nauką zyskało w początku XIX wieku. Niedługo później (1824 r.) w Londynie powstał budynek Athenaeum $\mathrm{Club}^{4}$, w którym znajdowała się bogata biblioteka, miejsca do nauki, ale również różnego rodzaju sale przeznaczone zarówno do wypoczynku jak i rekreacji. Należały do nich np. jadalnia, pokój dzienny, kawiarnia, palarnia, pokój rysunku i inne. W późniejszym czasie jedną z sal przeznaczono na salę bilardową. Athenaeum Club nie było otwarte dla zwykłego ,,człowieka z ulicy”. Aby się tu pojawiać należało być osobą wybitną, bądź bardzo wpływową. Przyjęcie do klubu związane było ze ścisłymi zasadami - istniały rygorystyczne roczne limity przyjęć, listy oczekujących. Aby zarysować elitarność tego miejsca można wspomnieć, że do klubu należeli Charles Dickens, Charles Darwin, a aż pięćdziesięciu dwóch członków Athenaeum Club otrzymało nagrodę Nobla. ${ }^{5}$

Athenaeum czasów obecnych nie musi być już związane z elitarnością. Athenaeum autorstwa Richard Meier \& Partners Architects, ukończone w 1979 r. w New Harmony w Stanach Zjednoczonych jest obiektem zorientowanym na lokalną społeczność oraz zwiedzających. Budynek został zaprojektowany tak, aby pełnić centrum różnych wydarzeń dla mieszkańców oraz jako pewnego rodzaju muzeum, szlak zwiedzania dla przyjezdnych, umożliwiający zapoznanie się z historią miasteczka. ${ }^{6}$ Jednym z najważniejszych elementów budynku jest rampa, prowadząca zwiedzających przez trzy kondygnacje. Jest ona głównym ciągiem komunikacyjnym, zorientowanym na takie kierowanie użytkowników, aby mogli w odpowiedni sposób podziwiać ekspozycję, widoki na zewnątrz oraz mieli jak najłatwiejszy dostęp do głównych pomieszczeń, takich jak audytorium na dwieście osób czy jedną z czterech galerii. Ten wielofunkcyjny budynek otrzymał w 2008 r. roku prestiżową nagrodę 25-lecia, przyznawaną budynkom i strukturom, they do it? The analyses presented in this paper are intended to provide the best possible understanding of the sociological and historical climate that has affected present-day Rio de Janeiro architecture. The study's findings are also a starting point for formulating guidelines for the design of the Athenaeum of Twenty-first Century Architecture. It is intended to familiarise people with the history of architecture in a typically museum- or book-like style while also being a place that invites one to explore architecture's evolution and what it is in an unobvious, modern, interactive, surprising and inspiring way.

\section{ATHENAEUM}

An athenaeum is a place that serves science or to promote science and culture. ${ }^{2} 3$ This term often denotes a building that includes a library and spaces for reading and learning. The etymology of the word athenaeum leads to the first Athenaeum-a school of Fine Arts in ancient Rome, which owed its name to the Greek word athenaion, which denoted a temple of Athena, the goddess of wisdom. In ancient Greece, buildings bearing this name were the sites of lectures delivered by professors from various fields, while actors and poets could prepare for performances or create their works there. The word gained its contemporary meaning as a place associated with broadly understood science at the beginning of the nineteenth century. Shortly afterwards, the Athenaeum Club was built in London, ${ }^{4}$ which housed a well-equipped library, places to study and all kinds of halls for both rest and recreation. These included a dining hall, a day room, a café, a smoking room, a drawing room and other facilities. Later on, one of the spaces was converted into a pool hall. The Athenaeum Club could not be freely entered. Admittance was given only to outstanding or highly influential figures. Membership in the Club was tied with strict rules-there were rigorous limits on new yearly memberships and waiting lists. The Club's elite status was attested by the fact that its members included Charles Dickens and Charles Darwin and as many as fifty-two of the Athenaeum Club's members were Nobel prize laureates. ${ }^{5}$

A present-day athenaeum does not have to be tied with the elite. The Athenaeum by Richard Meier \& Partners Architects, completed in 1979 in New Harmony in the United States of America, is a building oriented towards the local community and visitors. The building was designed so as to act as a centre of various community events and a form of a museum, a touring route for visitors, allowing them to familiarise themselves with the town's history. ${ }^{6}$ One of the most important elements of the building is a ramp that leads visitors along three levels. It is the main circulatory path sequence, oriented to direct users so that they can view the exhibition and the outside in a specific manner, and provides them with the easiest possible access to the building's main spaces, such as an auditorium for 200 people or either of its four galleries. This multi-functional building received the prestigious quadranscentennial award, given to buildings and structures that have existed for 25 to 35 years and meet requirements like high aesthetic val- 
które istnieją od 25 do 35 lat i spełniają takie wymagania jak: wysokie walory estetyczne, kreatywny zamysł koncepcji oraz ,przetrwanie próby czasu". Ten ostatni termin oznacza m.in. to, że taki obiekt powinien być wciąż w dobrym stanie (technicznym i estetycznym), a przy tym nie powinien przez wszystkie lata funkcjonowania za bardzo zmienić wizerunku tak, aby pierwotny zamysł architekta został zachowany. Athenaeum w New Harmony to budynek, który „,przetrwał próbę czasu”nie tylko pod względem estetyki i swojej „czystej architektury", również dlatego, że nadal z powodzeniem pełni rolę wielofunkcyjnego miejsca poświęconego historii, nauce oraz rekreacji. Dodatkowo jest to miejsce, które za pomocą architektury stara się angażować zwiedzających w poznanie miasteczka New Harmony zarówno wewnątrz - przez formowanie rampy i odpowiednie nakierowywanie uczestników na elementy ekspozycji, jak i na zewnątrz - przez ukształtowanie przeszkleń w taki sposób, aby z wnętrza budynku można było jak najlepiej widzieć lokalny krajobraz.

Słowo "Athenaeum” zmieniało swoje znaczenie w różnych momentach historii. Athenaeum dzisiejszych czasów można określić jako miejsce, które w wielozmysłowy sposób inspiruje i angażuje zwiedzających do poznawania tego, co oscyluje wokół danej tematyki za pomocą mniej lub bardziej oczywistych środków wyrazu.

\section{RIO DE JANEIRO. \\ KONTRASTY A ARCHITEKTURA KULTUROTWÓRCZA}

Ogłoszone Stolicą Światowej Architektury na rok 2020 Rio de Janeiro, licząca dwanaście milionów mieszkańców metropolia jest odbiciem kontrastów obecnych na Ziemi. Niezwykły krajobraz tego miejsca - atrakcyjne ukształtowanie terenu, wspaniałe plaże, fauna i flora, intrygująca kombinacja obecnej tam architektury styka się z takimi problemami jak: walki gangów, przestępczość narkotykowa, czy wysoki wskaźnik zabójstw. Miasto dotykają te same problemy co resztę kraju: duże rozwarstwienie społeczne, a co za tym idzie majątkowe, problemy związane z infrastrukturą i środowiskiem, a także wszechobecna korupcja. (Malinowska-Petelenz, Ludwin, 2018), (Siedlecki, Markiewicz, 2018), (Skaza, Twardowski, 2019)

Fawele (Malinowska-Petelenz, Ludwin, 2018), (Siedlecki, Markiewicz, 2018),

Od 1532 r. do 1888 r. do Brazylii przywiezionych zostało ok. pięć milionów niewolników z Afryki. Do Rio de Janeiro trafiło ich ok. dwa miliony. Brazylia wcieliła ich najwięcej spośród państw na świecie, a jednocześnie była ostatnim państwem które zniosło niewolnictwo (w 1888 r.) Dużą część rządu stanowili ludzie, którzy czerpali wcześniej wielkie korzyści z istnienia niewolnictwa. Nie było $w$ ich interesie, aby pomóc wyzwolonym niewolnikom. „Favela" to nazwa pochodząca od rośliny (fasoli fava), która porastała wzgórza Rio de Janeiro pod koniec XIX wieku. Na nich postanowili osiedlić się najpierw wyzwoleni niewolnicy, a następnie dwadzieścia tysięcy weteranów, którzy pozostali bez miejsca do życia. ${ }^{7}$ Jedyna możliwość jaką mieli, to wybudować swoje własne „,wioski" bez współudziału i pomocy władz miasta. ue, a creative design concept or that have 'stood the test of time'. This last term means that such a building should, among other things, be in good condition (both technically and aesthetically). Its image and functioning should also remain largely unchanged, so as to preserve the original intent of the architect. The Athenaeum in Hew Harmony is a building which 'has stood the test of time' and not just in terms of its aesthetic and 'pure architecture'. It also successfully acts as a multi-functional place devoted to history, science and recreation. In addition, it is a place that tries to use its architecture to engage visitors in familiarising themselves with the town of New Harmony both inside-via the form of its ramp and proper direction of users towards exhibition elements-and outside, by a glazing design that allows the local landscape to be easily seen from inside the building.

The name 'athenaeum' had different meanings at different points in history. The contemporary athenaeum can be described as a place that inspires and engages visitors in a multi-sensory manner to experience that which oscillates around a given subject via more or less obvious means of expression.

\section{RIO DE JANEIRO: CONTRASTS VERSUS CULTURE-FORMING ARCHITECTURE}

Declared the World Capital of Architecture for 2020, Rio de Janeiro, a metropolis with 12 million inhabitants, is a reflection of our planet's contrasts. The extraordinary landscape of this place-its attractive terrain, wonderful beaches, fauna and flora, and an intriguing combination of local architecture exist side-by-side with problems like gang wars, drug-related crime or high homicide rates. This city is affected by the same problems as the rest of the country: considerable social and thus financial inequalities, infrastructural and environmental problems, as well as widespread corruption. (Malinowska - Petelenz, Ludwin, 2018), (Siedlecki, Markiewicz, 2018), (Skaza, Twardowski, 2019)

Favelas (Malinowska-Petelenz, Ludwin, 2018), (Siedlecki, Markiewicz, 2018)

Between 1532 and 1888, around 5 million slaves were transported from Africa to Brazil. Rio de Janeiro received around 2 million of these slaves. Brazil took in more of them than any of the world's countries, while also being the last to abolish slavery (in 1888). A large part of the country's government was comprised of people who profited greatly from slavery. It was not in their interest to help freed slaves. The 'favela' is a term derived from the name of a plant (the fava bean) which used to grow on the hills around Rio de Janeiro towards the end of the nineteenth century. These hills were first settled by freed slaves and later by 20 thousand veterans who had been left without a place to live. ${ }^{7}$ The only option left to them had been to build their own 'villages' without the participation and aid of the city's administration. At present, favelas are inhabited by close to 1.5 million people, which is between $23 \%$ and $24 \%$ of Rio's residents. ${ }^{8}$ The favelas are thus inhabited by only 250 thousand people less than all of the inhabitants of Warsaw. Is the name 'favela' the equivalent of slums? This type of poverty- 
Obecnie fawele zamieszkuje blisko półtora miliona ludzi, czyli $23 \%$ do $24 \%$ mieszkańców Rio. ${ }^{8} \mathrm{~W}$ fawelach mieszka zatem tylko o ok. dwieście pięćdziesiąt tysięcy mniej osób niż w Warszawie. Czy nazwa fawele jest równoznaczna ze slumsami? Ten określany jednym terminem rodzaj dzielnic ubóstwa, to w istocie ponad tysiąc różnych typów faweli. Różnią się one od siebie pod bardzo wieloma względami. Największa z nich - Rocinha, uznawana również za jedną z najgroźniejszych, zamieszkiwana jest oficjalnie przez siedemdziesiąt tysięcy osób, a nieoficjalnie nawet dwieście dwadzieścia tysięcy. Infrastruktura tej dzielnicy jest jedną z dwudziestu dwóch najlepszych, w porównaniu do pozostałych faweli. Większość domów zbudowana jest z żelbetu bądź pustaków i posiada dostęp do wody, kanalizacji, elektryczności i Internetu. Jednak woda i elektryczność w zdecydowanej większości wszystkich faweli jest przez mieszkańców kradziona. Nielegalne podpinanie się do przewodów elektrycznych jest nie tylko niezgodne z prawem (choć wszyscy to robią), ale też niebezpieczne. Jednak dzięki temu mieszkańcy płacą jedynie za Internet. W Rocinha poza lokalnymi biznesami mieszkańców znajdują się także banki czy lokale dostawców telewizji kablowej. Te pozory normalności kontrolowane są jednak przez groźne grupy przestępcze. ${ }^{9}$ Mieszkańcy Rocinha i pozostałych faweli czasem mówią o sobie, że zło spotyka ich ponieważ są niewidoczni dla Boga - gdyż znajdują się "za plecami Chrystusa". Chodzi oczywiście o fakt położenia z tyłu pomnika Chrystusa Zbawiciela. ${ }^{10}$ Mimo poważnych problemów, fawele stają obecnie się atrakcjami regionu. Turystyka $w$ wielu z nich rośnie z roku na rok. Jednym z powodów zainteresowania nimi jest ich różnorodność i feria koloru. Poza opisaną Rocihna, do znanych faweli należy np. Fawela Tavares Bastos - pełna muzyki i barwnego nocnego życia. Była ona wielokrotnie tłem dla znanych filmów i teledysków. Cidade de Deus - z portugalskiego Miasto Boga, to fawela wybudowana w 1960r. z polecenia władz miasta. To głównie w niej toczy się oparte na faktach życie bohaterów powieści Paula Linsa, wydanej 1997r. W 2002r powstał na jej podstawie słynny film o tej samej nazwie (Miasto Boga). Jednak prawdopodobnie najbardziej znana jest Fawela Santa Marta, w której Michael Jackson nakręcił w 1995 roku znany teledysk "They Don't Care About Us". To właśnie w tej faweli zrealizowany został sławny projekt dwójki holendrów Haas \& Hahn, którego efektem było pomalowanie trzydziestu czterech budynków w niekonwencjonalny sposób w żywe, tęczowe kolory podnoszące walory estetyczne miejsca z wielu punktów obserwacyjnych. Kolorowe wzory prezentują przed widzem różne rodzaje całości zależnie od miejsca, z którego je ogląda. Głównym celem projektu było podniesienie poczucia wartości mieszkańców, pozytywnej przynależności. Względnie niewielka fawela Vidigal to zdecydowanie fawela najbardziej przyjazna i dostępna dla turystów. Znajduje się w doskonałym miejscu - na wzgórzu pod górą Dwóch Braci, bezpośrednio przy oceanie, z widokiem na plażę Leblon. ${ }^{11}$ Vidigal już wcześniej była popularna wśród obcokrajowców i słynna ze wspa- stricken district is actually over a thousand different types of favelas. They differ from each other in many aspects. The largest-Rocinha—believed by some to also be one of the most dangerous, is officially inhabited by 70 thousand people, and unofficially by even up to 250 thousand. The infrastructure of this district is among the top twenty of the remaining favelas. Most houses here are built from reinforced concrete or concrete masonry units and have access to running water, sewerage, electricity and the Internet. However, water and electricity is largely acquired by the inhabitants of most favelas illegally. Unlawful connections to electric power grids are not only against the law (although they are widespread) but are also dangerous. However, this means that local residents only pay for the Internet. In Ronciha, apart from local businesses, there are banks or cable provider branches. However, although they may keep up appearances of normality, they are mostly controlled by dangerous organised crime syndicates. ${ }^{9}$ The residents of Rocinha and the remaining favelas sometimes say that they are beset by misfortune because they are invisible to God-as they are 'behind Christ's back'. This is of course a reference to their location behind the statue of Christ the Redeemer. ${ }^{10}$

Despite significant problems, favelas are currently becoming one of the region's attractions. Tourism has been steadily rising in many of them. One of the reasons behind this interest is their diversity and wealth of colour. Apart from Rocinha, other well-known favelas include Tavares Bastos-which is filled with music and has colourful nightlife. It was often used as film or music clip setting. Cidade de Deus-City of God in Portuguese-is a favela built in 1960 on the orders of the city's administration. It is also the primary setting of the life of the protagonists of a 1997 novel by Paul Lins. In 2002, a famous film was made with the same name (City of God). However, it is the Santa Marta favela that is probably the most famous, as it is here that Michael Jackson filmed his music clip to the song 'They Don't Care About Us' in 1995. The favela is also the site of a famous project by a duo of Dutch designers named Haas \& Hahn, which resulted in the unconventional repainting of thirty-four buildings into bright, rainbowlike colours which improve the area's aesthetic when viewed from many observation points. The colourful patterns present before the observer different types of wholes depending on the place from which they are viewed. The main objective of the project was to improve the sense of self-worth and positive belonging among the local population. The relatively small favela Vidigal is decidedly the most friendly and accessible to tourists. It is located in a perfect location-on a hill at the foot of the Two Brothers Mountain, directly on the ocean coast, with a view of Leblon Beach. ${ }^{11}$ Vidigal had been popular with foreign tourists much earlier due to its unique cultural and night life, owed to the presence of the local artistic community. What currently distinguishes this favela from most others is the presence of an increasing number of hostels, bars, clubs and restaurants. Despite high crime rates, the distinguishing feature of most favelas are their closely-knit communities. 
niałego życia kulturalnego i nocnego, zawdzięczanemu obecności bohemy artystycznej należącej do tego miejsca. Co odróżnia obecnie tą fawelę od większości pozostałych, to obecność coraz większej ilości hosteli, barów, klubów i restauracji. W fawelach, pomimo wysokiego poziomu przestępczości, charakterystyczną cechą są ich zżyte społeczności.

\subsection{Architektura kulturotwórcza}

Aby dobrze zrozumieć ,"klimat" architektury Rio de Janeiro, w szczególności budynków muzealnych, galerii i innych o głównej funkcji edukacyjno-rekreacyjnej i kulturowej, poniżej przedstawione zostały przykłady odpowiadające tej tematyce. W celu przeprowadzenia całościowej i uporządkowanej analizy przedstawionych tu budynków wykorzystana została m.in. metoda zaprezentowana w książce pt. „Elementy nowoczesnej architektury. Zrozumieć współczesne budynki". (Radford, Morkoc, Amit, 2017, s. 12-28) Zastosowana hierarchia analizy jest sumą pytań dotyczących kontekstu: Jaka jest lokalizacja budynku? W jaki sposób przekłada się ona na lokalne i globalne aspekty, dotyczące środowiska naturalnego, krajobrazu i klimatu? Jaka jest interakcja z elementami krajobrazu lub budynkami mającymi związek z analizowanym obiektem? Czy obiekt odnosi się do lokalnej kultury i architektury? Jeśli tak, to w jaki sposób? Jakie są najważniejsze aspekty dotyczące formy budynku? Jakie stwarza wrażenie? Jak ma się konstrukcja budynku do jego całości? Jak detale obiektu odnoszą się do całokształtu? Jakie wykorzystano materiały i dlaczego te? W jaki sposób użytkownicy wchodzą i wychodzą z budynku, jak się w nim poruszają? Jak odczuwają formę, przestrzeń i symbolikę w budynku i jego obrębie? W jaki sposób przestrzeń w budynku angażuje zwiedzających?

\subsubsection{Muzeum Sztuki Nowoczesnej, proj. Affonso Edu- ardo Reidy ${ }^{12}$}

Muzeum Sztuki Nowoczesnej w Rio de Janeiro (z portugalskiego Museu de Arte Moderna, MAM) zlokalizowane jest przy wybrzeżu zatoki Guanabara, w północno - wschodniej części parku Flamengo. Budynek został utworzony w miejscu, gdzie znajdowało się kiedyś wysypisko śmieci w ramach projektu ,odzyskania ziemi".

\section{Kontekst}

Lokalizacja budynku współgra z krajobrazem na zasadzie kontrastu. Mocna, horyzontalna bryła główna ma sprawiać wrażenie wyrazistej formy na tle falującej linii wzgórz, znajdujących się po drugiej stronie zatoki. Z wybrzeża gdzie znajduje się MAM roztacza się piękny widok na zatokę i Głowę Cukru. Dzięki wolnemu parterowi pod galerią, zmierzający w kierunku muzeum mogą zobaczyć park i zatokę pod główną bryłą budynku. Efekt ten uzyskany jest dzięki wsparciu i podwieszeniu muzeum na charakterystycznych zewnętrznych filarach. Proporcje gabarytu podniesionej bryły budynku w stosunku do wolnej przestrzeni pod nim nie dają jednak wrażenia pełnego otwarcia widokowego tworząc wrażenie „szpary widokowej”, przez którą można „podejrzeć" przestrzeń znajdującą się za budynkiem.

\subsection{Culture-forming architecture}

To properly understand the 'atmosphere' of Rio de Janeiro's architecture and particularly its museums, galleries and other educational, recreational and cultural buildings, examples of such have been presented below. To perform a holistic and structured analysis of these buildings, the authors used, among others, the method presented in Elementy nowoczesnej architektury. Zrozumieć współczesne budynki. (Radford, Morkoc, Amit, 2017, pp. 12- 28) The analysis hierarchy applied is a sum of questions concerning context. What is the building's location? How does it carry over to local and global aspects concerning the natural environment, the landscape and climate? What is the interaction with elements of the landscape or buildings linked with the building under analysis? Does the building refer to local culture and architecture and if so, then how? What are the key aspects of the building's form? What impression does it make? How does the structural system of the building refer to its whole? How do the details of the building refer to its entirety? What materials were used and why? How do people exit and enter the building and how do they move inside it? How do they experience form, space and symbolism within the building and outside of it? How does the space inside the building engage its visitors?

\subsubsection{Museum of Modern Art, designed by Affonso Eduardo Reidy ${ }^{12}$}

The Museum of Modern Art in Rio de Janeiro (Museu de Arte Moderna, MAM in Portuguese) is located near the Guanabara Bay coast in the north-eastern part of Flamengo Park. The building was sited on a former landfill, as a part of a 'land reclamation' project.

\section{Context}

The site of the building is in a contrasting relationship with the landscape. Its strong, horizontal main body is intended to produce an impression of an expressive form against the background of the undulating ridgeline of the hills on the other side of the Bay. From the coast where the MAM is located there is a beautiful view of the Bay and Sugarloaf Mountain. Due to the free ground floor underneath the gallery, those walking towards the museum can see the park and the Bay underneath the main body of the building. This effect has been obtained via the support of and suspension of the museum from distinct external columns. The proportions of the volume of the elevated mass of the building relative to the free space underneath do not produce an impression of a complete visual opening, instead appearing to be a 'viewing slit', through which one can 'peek at' the space located behind the building.

Form and Technology

The Rio de Janeiro Museum of Modern Art is a building divided into three sections: a gallery, a slightly 'hidden' administrative and technical building and a theatre. These forms are interconnected, both functionally and in terms of the impression of comprising a whole. The columns, which are the museum's most distinct elements, contrast with the glazing of the horizontal mass and give it a dynamic quality. This exposed structure is also the primary element 


\section{Forma i Technologia}

Muzeum Sztuk Współczesnych Rio de Janeiro to obiekt podzielony na trzy części: galerię, lekko „ukryty" obiekt administracyjno-techniczny oraz teatr. Formy są ze sobą połączone, zarówno pod względem funkcjonalnym, jak i wrażenia całości, którą tworzą. Najbardziej charakterystyczne dla muzeum filary kontrastują z przeszkleniami horyzontalnej bryły i dodają jej dynamiki. Ta wyeksponowana konstrukcja jest jednocześnie podstawowym elementem budującym wizerunek budynku. Starannie dobrana zieleń (projektowana przez Burle Marx'a) - znajduje się na dachu budynku administracyjnego, który składa się w dużej części z obszernego tarasu. W basenach przed frontową częścią muzeum i teatrem rosną nenufary i inna wodna roślinność. Trawniki zaprojektowano tak, aby tworzyły taki sam wzór jak mozaika przed głównym wejściem do budynku - charakterystyczne fale, obecne również w posadzkach przy plażach w innych miejscach Rio.

Funkcja i Ludzie

Głównym założeniem funkcjonalnym obiektu było stworzenie centrum skupiającego wszelkiego rodzaju wydarzenia i życie kulturalne. Poza muzeum i galerią założenie zawiera również bibliotekę oraz miejsca do pracy, przygotowań do występów i prowadzenia warsztatów i wykładów. Teatr umożliwia organizację koncertów, spektakli teatralnych, baletu, wyświetlania filmów i organizację konferencji. Wejścia do budynków są połączone za pomocą tarasów widokowych na wysokości pierwszego piętra. Przestrzeń muzeum jest bardzo elastyczna. Umożliwia podział wnętrza na różne sposoby. Jest to możliwe dzięki przeniesieniu charakterystycznych filarów konstrukcyjnych na zewnątrz. Dzięki temu muzeum nie jest ograniczone przez wewnętrzne elementy konstrukcyjne. Zróżnicowanie wysokości tego budynku (od 3,6 metra do 8 metrów), pozwala na umieszczanie dzieł sztuki o mocno różniących się rozmiarach. Jednym z najbardziej charakterystycznych elementów wnętrza budynku są szerokie schody na planie koła, z których zwiedzający przemieszczają się pomiędzy parterem a pierwszym piętrem. Podróż po muzeum to dla użytkownika udział w grze świateł. Podziały umiejętnie zabierają i oddają światło z zewnątrz, czasem niemal z zaskoczenia. Zróżnicowanie załamań ścian ekspozycji wewnątrz i otwierania się na światło z zewnątrz związane jest z ideą umożliwienia zwiedzającemu kontemplacji sztuki na różne sposoby, skupienia się na elementach wystawy, ale także szansę zrobienia sobie chwilowej przerwy - odświeżenia umysłu dzięki spojrzeniu na piękny widok za oknami, a następnie powróceniu do kontemplacji sztuki z nieco świeższym spojrzeniem. To miejsce nadal ,żyje”, sześćdziesiąt cztery lata od jego wybudowania.

\subsubsection{Muzeum Sztuki Współczesnej w Niterói, proj. Oscar Niemayer}

Muzeum Sztuki Współczesnej w Niterói znajduje się przy zatoce Guanabara. Komunikacja pomiędzy Niterói a Rio możliwa jest za pomocą promów, lub mostem łączącym miasta. that builds the building's image. Carefully selected greenery (designed by Burle Marx) is located on the roof of the administrative building, which is largely composed of an expansive terrace. The pools near the frontal part of the museum and theatre are used to grow nenuphars and other aquatic greenery. The lawns were designed to form the same pattern as the mosaic in front of the building's main entrancewith distinctive waves, which are also present on the floors near beaches and other places in Rio.

\section{Function and People}

The main functional assumption behind the building's design was to create a centre for all manners of events and cultural life. Apart from including a museum and a gallery, the complex also features a library and places for work, preparation for performances and the hosting of workshops and lectures. The theatre allows for the organisation of concerts, theatre spectacles, ballet performances, film screenings and conferences. The entrances to the buildings are connected via observation decks at the level of the first floor. The museum space is highly flexible. Its interior can be partitioned in numerous ways. This is possible due to the relocation of the distinctive structural columns outside. This makes the internal space of the museum free from structural constraints. The height differences of this building (from $3.6 \mathrm{~m}$ to $8 \mathrm{~m}$ ) allows the exhibition of artworks of varying sizes. One of the most distinct elements of the building's interior are wide stairs with a circular plan, which allow movement between the ground floor and the first floor. To the user, to move through the museum is to participate in a game of light. The partitions skilfully restrict and release light from the outside, sometimes doing so in quite a surprising manner. The variation in the exhibition space's wall shape inside and the opening towards the light from outside are associated with the concept of enabling visitors to contemplate art in various ways, to focus on elements of the exhibition and to provide an opportunity for a momentary break-to refresh one's mind with a beautiful view from out the window-only to return to contemplating art with a slightly fresher gaze. This place still 'lives' sixty-four years after its construction.

\subsubsection{Niterói Contemporary Art Museum, designed by Oscar Niemeyer}

The Niterói Contemporary Art Museum is located near Guanabara Bay. Circulation between Niterói and Rio is provided by ferries and a bridge that connects both cities.

\section{Context}

In landscape terms, the museum's site is exceptionalit defines the shape of the building, via an attempt at the maximum possible 'appreciation' of the beauty of these surroundings. On the other side of the Bay is Rio de Janeiro and the perfectly visible Sugarloaf Mountain. There is also a small picturesque monastic island nearby, with the Igreja da Boa Viagem Church (Church of the Good Voyage). The museum has the expression of a symbolic lighthouse that 'stands vigil' over the area. The design of the complex was motivated by the desire to highlight the visual assets of the surroundings. Oscar Niemeyer, when describing the process of 
Kontekst

Lokalizacja muzeum pod względem krajobrazowym jest wyjątkowa - to z niej wynika kształt budynku, a dokładniej z próby maksymalnego „,docenienia" piękna tego otoczenia. Po drugiej stronie zatoki znajduje się Rio de Janeiro, oraz doskonale widoczna Głowa Cukru. W bliskiej odległości znajduje się również malownicza, mała wyspa klasztorna z kościołem Igreja da Boa Viagem (Dobrej drogi). Muzeum ma wyraz symbolicznej latarni morskiej, „czuwającej" nad okolicą. Projekt założenia wynikał z chęci podkreślenia walorów widokowych otoczenia. Oscar Niemeyer opisując proces powstawania koncepcji powiedział, że ze względu na wąski pas działki otoczonej morzem, rozwiązanie polegające na konstrukcji muzeum opartej wokół centralnego „,punktu", przyszło naturalnie. Od tego początku reszta architektury pojawiła się niemal spontanicznie, jak wyrastający ze skały kwiat.

\section{Forma i Technologia}

Ten mierzący 16 metrów wysokości budynek o średnicy 50 m sprawia wrażenie nieco ,nieziemskiego", niemal dosłownie, ponieważ przypomina kosmiczny obiekt. Ekscentryczna w wyrazie rampa, prowadząca do głównego wejścia, wykończona jest intensywnie czerwonym betonem. Przypomina nieco luksusowy dywan, zaprojektowany dla gwiazd Hollywood odbierających prestiżowe nagrody w błysku fleszy. Horyzontalne, pochyłe okna, biegnące naokoło części wystawowych umożliwiają zwiedzającym doskonały widok na otaczającą okolicę. Pod muzeum, na poziomie terenu, znajduje się płytki basen. Istnieje dla względów estetycznych, odbijania muzeum (nadawania mu tym samym pewnej lekkości) oraz wzmacniania ciekawych efektów świetlnych podczas podświetlania budynku. Jeden z najważniejszych powodów istnienia basenu to wrażenie optycznego „,połączenia" wody z tego płytkiego zbiornika z wodą morską zatoki. Konstrukcja terenu jest bezpośrednio połączona z całokształtem budynku. Całość opiera się na masywnych ścianach, otaczających trzon komunikacyjny, który prowadzi do kondygnacji podziemnej. Pod względem doboru materiałów, wykończenie muzeum jest oszczędne. Zarówno na zewnątrz jak i wewnątrz jest to pomalowany na biało żelbet oraz fasada okienna o nachyleniu $40^{\circ}$.

\section{Funkcja i Ludzie}

Do muzeum prowadzą trzy wejścia. Dwa z nich, to wejścia główne, do których należy przejść przez efektowną, czerwoną rampę. Rozdzielająca się na dwa „pasma" rampa, kończy bieg na pierwszym i drugim piętrze. Szklane wejścia, w które trafia rampa, znajdują się dokładnie nad sobą. Trzecie wejście do budynku, prowadzące do kondygnacji podziemnej, wkomponowane jest w przestrzeń kolistego baseniku pod muzeum. Jest w pewnym sensie „ukryte”, ponieważ z daleka nie widać żadnego elementu sygnalizującego jego istnienia, a składa się z kręconych schodów na planie koła, bezpośrednio zagłębionych w terenie. To wejście prowadzi do kondygnacji podziemnej, w której jest restauracja, audytorium na około 60 osób oraz magazyny i zaplecze techniczne. Na pierwszym piętrze znajduje się recepcja, biura administracji oraz dostęp do wysokiego, sześcio- preparing the conceptual proposal, said that due to the narrow strip formed by the site, which is surrounded by the sea, the design, which featured placing the structure of the museum as anchored around a central 'point' had come naturally. From this starting point, the remaining part of the architecture emerged almost spontaneously, as if a flower growing out of a rock.

\section{Form and Technology}

The building, with a height of $16 \mathrm{~m}$ and a diameter of $50 \mathrm{~m}$, produces an impression of being slightly 'otherworldly', and almost literally so, as it resembles a spaceship. An eccentrically expressive ramp that leads to its main entrance is finished with intensely red concrete. It somewhat resembles a luxurious carpet, designed for Hollywood stars who receive prestigious awards in the spotlight. Horizontal, slanted windows that run along the exhibition sections provide visitors with an excellent view of the surrounding area. Underneath the museum, at ground level, there is a shallow pool. It was placed there for aesthetic reasons, to reflect the image of the museum (and thus provide it with a certain lightness) and enhance interesting light effects as the building is illuminated. One of the major reasons for the existence of the pool is to produce an impression of the optical 'linking' of the water in this shallow pool with the seawater in the bay. The structure of the terrain is directly linked with the entirety of the building. It is supported by massive walls that surround the circulation core, which leads to the underground storey. In terms of material selection, the museum has an austere finish. It is concrete painted white both inside and outside, as well as a window facade with an angle of $40^{\circ}$.

Function and People

The museum can be entered via three entrances. Two of these are main entrances, which can be reached via the impressive, red ramp. The ramp, which splits into two 'strips', ends at the first and second floors. The glass entrances that the ramp leads to are situated directly above one another. The third entrance to the building, which leads to its underground storey, is composed into the space of a circular pool underneath the museum. It is, in a sense, 'hidden', as from afar no element that would signal its existence is visible, and it is comprised of a set of spiral stairs with a circular plan, which are directly embedded in the terrain. This entrance leads to an underground level with a restaurant, an auditorium for around 60 people and storage and infrastructural spaces. On the first floor there is a reception space, offices and access to a tall, hexagonal room - the main hall, surrounded by a circular observation platform, which allows one to see the view outside. The main hall features various types of exhibits that 'need height', including engaging ones, such as hammocks for visitors, suspended along the entire height of the space. The second floor, which is lower than the remaining ones, is intended for exhibitions. It has windows that surround the floor along its entire height. The final level-the third floor-is a place completely blocked off from light, without windows, and divided into five exhibition galleries. The museum affects its visitors primarily by how it acts in concert with the beautiful surroundings and thanks to its simplicity. 
kątnego pokoju - sali głównej, otoczonej przez widokowy ciąg pieszy, pozwalający na podziwianie widoków na zewnątrz. Sala główna to miejsce różnorodnych ekspozycji, które „potrzebują wysokości", w tym także angażujących, jak np. hamaki dla zwiedzających, rozwieszone na całej wysokości pomieszczenia. Drugie piętro, niższe od pozostałych, przeznaczone jest na wystawy. Posiada okna naokoło piętra, na całej jego wysokości. Ostatni poziom - trzecie piętro, to część całkowicie zaciemniona, bez okien, podzielona na pięć galerii przeznaczonych na wystawy. Muzeum oddziałuje na zwiedzających głównie dzięki współgraniu z walorami pięknego otoczenia oraz swojej prostocie. Polega ona na konkretnym, wyrazistym pomyśle oraz limitowanej ilości środków wyrazu. Te elementy odnoszą się do lokalnej architektury modernistycznej (minimalizm, odbicia w płytkich basenach). Funkcja jest tu w zgrabny i ciekawy sposób połączona z formą.

\subsubsection{Muzeum Jutra, proj. Santiago Calatrava}

Muzeum Jutra zlokalizowane jest niedaleko centrum miasta, na sztucznej wyspie przylegającej do lądu, w zatoce Guanabara. Wysokość budynku w najwyższym punkcie -osiemnaście metrów - wynika z ochrony widoku znajdującego się w bliskiej odległości klasztoru Sao Bento, wpisanego na listę dziedzictwa światowego UNESCO.

\section{Kontekst}

Muzeum zorientowane jest w kierunku północ-południe, z delikatnym przechyleniem osi w kierunku wschodnio-zachodnim. Takie usytuowanie pozwala na jak najlepszy widok z terenu obiektu na atrakcyjną okolicę wybrzeża Rio de Janeiro. Lokalizacja muzeum ma związek z ideą przewodnią budynku - zwrócenia uwagi na historię, obecne na świecie problemy i próbą odpowiedzi na pytanie jak można poprawić sytuację. Strefa wybrzeża, w której wybudowano muzeum, była i jest terenem, na którym toczą się intensywne działania rewitalizacyjne. Muzeum promuje integrowanie różnych społeczności miasta, krajobraz, historię, kulturę i rozrywkę. Ważna w kontekście lokalizacji muzeum jest jego bezpośrednia bliskość do placu Mauá oraz Muzeum Sztuki MAR, które przylega do tego placu. Wszystkie te elementy tworzone były tak, aby stworzyć spójną całość.

Forma i Technologia

Forma muzeum ma swoje korzenie w wizycie Santiago Calatravy w ogrodzie botanicznym Rio de Janeiro. Architekta znanego z tworzenia mnóstwa szkiców oraz akwareli, zaintrygował złożony kształt obecnych tam roślin z gatunku bromelii (krewnych ananasa). Początkowo Calatrava próbował stworzyć formę związaną z kształtem ludzkiego ciała, w związku z faktem, że budynek próbuje odpowiedzieć na pytanie gdzie znajduje się człowiek w historii świata i jak na nią wpływa. Po wizycie w ogrodzie botanicznym architekt został na tyle zainspirowany rodziną bromelii, że połączył wstępne pomysły z tą właśnie główną inspiracją.

Ideą Muzeum Jutra miało być zwrócenie w przyszłość i kreacja czegoś tak lekkiego, jakby chciało wzlecieć w powietrze i pofrunąć. Projektując Muzeum Jutra architekt wybrał podejście na zasadzie negatywu, przeci-
It is based on a specific, expressive idea and a limited number of means of expression. These elements refer to local Modernist architecture (Minimalism, reflections in shallow pools). Here, function is skilfully and interestingly combined with form.

\subsubsection{Museum of Tomorrow, designed by Santiago Calatrava}

The Museum of Tomorrow is located near the city centre, on an artificial island abutting the mainland in Guanabara Bay. The height of the building at its tallest point-18 $\mathrm{m}$-is a result of the need to protect the view of the nearby São Bento monastery, which is a UNESCO World Heritage Site.

\section{Context}

The museum is oriented along the north-south direction, with a slight tilt towards the east-west direction. This placement allows the best possible view of the attractive area of Rio de Janeiro's coast from the building's grounds. The location of the museum is associated with the overarching idea behind it-focusing attention to history, current world problems and attempting to find answers as to how to improve this situation. The coastal area in which the building is located has been the site of intense revitalisation efforts. The museum promotes the integration of the city's various communities, the landscape, history, culture and entertainment. Its close proximity to Mauá Square and the MAR Arts Museum, which abuts it, is important in the context of the Museum of Tomorrow's siting. All of these elements were designed to form a cohesive whole.

\section{Form and Technology}

The form of the museum is rooted in Santiago Calatrava's visit to Rio de Janeiro's botanical garden. The architect, known for creating a multitude of sketches and watercolours, was intrigued by the complex shape of the garden's bromelia plants (which are related to the pineapple). Initially, Calatrava tried to design a form associated with the shape of the human body, due to the fact that the building tries to answer the question about the place of humans in world history and how they affect it. After his visit to the botanical garden, the architect was inspired by the genus bromelia so much that he combined the initial ideas with this main inspiration. The idea behind the Museum of Tomorrow was to be an orientation towards the future and creating something so light as if it wanted to rise into the air and fly away. When designing the Museum of Tomorrow, the architect chose an approach based on the negative, of an opposite to the nearby São Bento monastery. The relationship between the buildings was described as being between the architecture of the mineral (earth-the monastery), and the architecture of air (of the sky and flight-the museum). The building's form brings to mind an aerodynamic machine that can fly. The metal elements of the roof structure resemble wings. Motion is one of their key functions-they rotate towards the sun, so as to collect as much solar energy as possible. The museum was built almost entirely of local materials. A system of water collection, purification and reuse was installed, in addition to a special air conditioning system 
wieństwa do pobliskiego klasztoru São Bento. Stwierdził że jeśli architektura klasztoru to architektura minerału (ziemi), to architektura muzeum jest architekturą powietrza, (nieba i lotu). Forma obiektu przynosi na myśl aerodynamiczną maszynę, która mogłaby latać. Metalowe elementy struktury dachu przypominają skrzydła. Ich bardzo ważną funkcją jest ruch - obracanie się w kierunku słońca, tak aby zebrać jak najwięcej energii słonecznej. Muzeum zostało zbudowane niemal całkowicie z lokalnych materiałów, zastosowano system zbierania i ponownego wykorzystania wody zdatnej do użytku oraz specjalny system klimatyzacji, który wykorzystuje wodę z zatoki Guanabara. Po wykorzystaniu wody system ją filtruje, oczyszcza i oddaje z powrotem za pomocą małego wodospadu. Woda zbierana jest również do basenu, okalającego muzeum z trzech stron. Basen pełni więc funkcje zarówno estetyczne (odbicia obrazu, efekty świetlne, wpływ na całościową estetykę budynku), jak i funkcjonuje jako zbiornik retencyjny.

\section{Funkcja i Ludzie $^{13}$}

Kreatywne podejście do ekspozycji oraz atrakcyjne tereny naokoło muzeum, to jedne z najważniejszych powodów bardzo wysokiego zainteresowania turystów tym obiektem. Już w pierwszym roku po otwarciu muzeum odwiedziło aż 1,4 miliona osób. Na parterze znajdują się sfera funkcjonalna oraz pokoje techniczne. Należą do nich biura administracji, zaplecze badawcze, audytorium, magazyn muzealny, restauracja, archiwum oraz sfera dostawcza. Pierwsze piętro to część przeznaczona głównie na komunikację - jest czymś w rodzaju półpiętra, przy okazji pełni rolę wewnętrznego tarasu widokowego. Ostatnie, drugie piętro to część główna muzeum - miejsce, w którym zlokalizowane są najważniejsze ekspozycje. Te wystawy podzielone są na pięć części, w następującej kolejności: Kosmos, Ziemia, Antropocen, Jutra i ostatnia - My. Ich układ nie jest przypadkowy - ekspozycje przechodzą od "ogółu do szczegółu”. Zależnie od tematyki każda z nich opowiada o historii, osiągnięciach nauki i problemach dzisiejszego świata. Początek tej podróży jest przede wszystkim opowieścią o świecie, w którym żyjemy. Im bliżej końca, tym więcej elementów związanych z działalnością człowieka, często taką, której negatywne konsekwencje czujemy dzisiaj oraz taką, którą „poczują" dopiero następne pokolenia. Wystawy nie mają jednak charakteru ,,pogróżkowego", są połączeniem faktów i naukowych badań przedstawionych w oryginalny, interaktywny sposób. Dają do myślenia, poprzez poruszanie tematów związanych z pytaniami, które są dopasowane do każdej z części. W kolejności układają się one w następujący sposób: Kosmos - Skąd pochodzimy? Ziemia - Kim jesteśmy? Antropocen - Gdzie jesteśmy? Jutra - Gdzie zmierzamy? My - Jak chcemy iść dalej? Muzeum we wnętrzu daje poczucie nowoczesności, spaceru w przestrzennym miejscu o zaokrąglonych kształtach, w których dominuje biel. Liczne przeszklenia dają możliwość podziwiania widoków na zewnątrz na każdym piętrze.

\subsection{Podsumowanie}

Przedstawione muzea są zarówno zupełnie odmienne pod względem form architektonicznych oraz niezwykle podobne jeśli chodzi o sposób myślenia nad tym, co jest ważne w architekturze. Każdy z obiektów zlokalizowany jest w bezpośredniej bliskości zatoki Guanabara. Każdy, na swój sposób umożliwia podziwianie piękna tego miejsca - zarówno z zewnątrz, that uses water from Guanabara Bay. After use, the system filters the water, purifies it and returns it using a small waterfall. Water is also collected into a pool that surrounds the museum from three sides. This pool has both an aesthetic function (it reflects the museum, provides lighting effects and impacts the overall aesthetic of the building) and is used as a reservoir.

Function and People ${ }^{13}$

A creative approach to exhibition and the attractive areas around the museum are some of the key reasons behind the very high interest in this building among tourists. The museum was visited by as many as 1.4 million people within the first year after it opened. The ground floor has a functional zone and technical spaces. These include administration office spaces, a research section, an auditorium, museum storage, a restaurant, an archive and a delivery zone. The first floor is a section primarily devoted to circulation-it acts as a sort of mezzanine, while also being an internal observation deck. The second, uppermost floor is the main section of the museum-a place that hosts the latest exhibitions. These exhibitions are divided into five sections, in the following sequence: Cosmos, Earth, Anthropocene, Tomorrow and, finally-Us. Their layout is not accidental-the exhibitions follow a 'top-down' scheme. Depending on the theme, each of them discusses history, scientific achievements and the problems of today's world. The start of this journey is primarily a story about the world we live in. The closer to the end, the more prominent the elements associated with human activity become, often of the kind whose negative consequences we feel today and the ones that will be 'felt' by the generations to come. However, the exhibitions are not 'threats', but are a combination of facts and scientific studies presented in an original, interactive manner. They make us think by touching on subjects linked to questions adapted to each section. In sequence, they are laid out as follows: Cosmos-where are we from? Earth-who are we? Anthropocenewhere are we? Tomorrow-where are we going? Us-how do we want to go forward? Inside, the museum gives off an atmosphere of modernity, of walking in a spatial place with curved shapes dominated by the colour white. Numerous glazed openings allow us to look outside at every floor.

\subsection{Summary}

The presented museums are completely different in terms of architectural forms and also highly similar in terms of the mode of thinking about what is important in architecture. Each of the buildings is located close to Guanabara Bay. In their own manner, each allows visitors to see the beauty of this place-both from inside and in the areas outside. Inside - via observation decks, broad strips of glazing and areas adapted to the peaceful contemplation of the view. Interweaving exhibitions with observation spaces is an essential measure that is present in all of the museums under analysis. Out- 
jak i w terenach na zewnątrz. We wnętrzu - poprzez tarasy widokowe, szerokie pasy przeszkleń oraz miejsca dostosowane do spokojnego kontemplowania widoków. Istotny zabieg charakterystyczny dla wszystkich analizowanych muzeów to przeplatanie wystaw z przestrzeniami widokowymi. Na zewnątrz muzea zapewniają atrakcyjne ciągi piesze ze specjalnie ukształtowaną zielenią czy wodą. Wszystkie trzy obiekty skonstruowane są tak, aby jak najmniej ,zzakłócać" widok na zatokę. Zaprojektowane obok, pod lub stykające się z budynkiem baseny istnieją dla celów estetycznych - odbić, ,ppołączenia" z wodą zatoki oraz podkreślania efektów iluminacji w nocy. W Muzeum Jutra baseniki mają dodatkowo funkcję zbiornika retencyjnego i dostarczania wody to filtracji. Funkcja, forma i konstrukcja w każdym z muzeów są scalone, wynikają z siebie i ,nie przeszkadzają" sobie nawzajem. Pomimo różnic formalnych, analizowane budynki posiadają istotne podobieństwa, a dzieli je różnica wielu lat. Pomiędzy Muzeum Sztuki Nowoczesnej MAM, a Muzeum Jutra różnica ta wynosi 70 lat. W tle zaś, na okolicznych wzgórzach przyciąga ferią barw krajobraz rodzimych faweli.

\section{WNIOSKI I WYTYCZNE DO PROJEKTU}

Rio de Janeiro to drugie pod względem wielkości po São Paulo miasto Brazylii. Sławny na całym świecie coroczny karnawał, fascynacja mieszkańców piłką nożną, plaże Copacabany, Pomnik Chrystusa Odkupiciela, czy Góra Cukru, wszechobecny kolor, kultura tubylców widoczna w życiu miasta, różnorodne style architektury - to tylko niektóre z wielu charakterystycznych znaków „rozpoznawczych" miasta. Korupcja, wysoki poziom przestępczości, czy problemy nękające fawele - to jego ciemne strony. Architektura ma zdolność wpływania na społeczeństwo, może sprzyjać jego aktywizacji. Celem Międzynarodowego konkursu "Athenaeum of the World Architecture '20"14 ${ }^{15}$ było zaprojektowanie budynku Athenaeum, który ma być miejscem poświęconym tematyce architektury - łączyć architekturę przeszłości i przyszłości, inspirować zwiedzających do odkrywania architektury w sposób inny niż dotychczas. Projekt ma być zlokalizowany właśnie w Rio De Janeiro, które zostało ogłoszone Światową Stolicą Architektury na rok 2020. To jest pierwszy rok nowej inicjatywy, zapoczątkowanej przez UNESCO oraz Międzynarodową Unię Architektów. Celem tego przedsięwzięcia jest rozpoczęcie międzynarodowej dyskusji, która ma zwrócić uwagę szerszych środowisk na te problemy obecnych czasów, na które rozwiązania architektury i urbanistyki mogą pomóc. Organizatorzy konkursu odnosząc się to do zmieniających się trendów w architekturze uznali, iż architekci nie projektują dziś już tylko ,samych budynków", ale coraz częściej - ekosystemy. Architektura zrównoważona, wydajna energetycznie i odpowiedzialna społecznie - to hasła, które z roku na rok powinny stawać się w coraz większym stopniu standardem w projektowaniu. Projekt Athenaeum ma w sobie łączyć te idee, biorąc pod uwagę zarówno kontekst historyczny miejsca, wyjątkową lokalizację (wybrzeże oceanu) jak i odpowiedź na zadanie konkursowe: odniesienie się do architektury przeszłości, teraźniejszości i zasugerowanie architektury przyszłości. To miejsce ma inspirować side, the museums provide attractive pedestrian path sequences with purpose-designed greenery or water. All three buildings are constructed so as to 'interfere' with the view of the Bay in the least amount possible. Pools designed either beside, underneath or to abut the buildings exist for aesthetic purposes-to reflect, to 'connect' with the waters of the Bay and to highlight the effects of illumination at night. In the Museum of Tomorrow, small pools also act as reservoirs and provide water for filtration. The function, form and structure in each museum are merged and each is the outcome of another, without 'interference'. Despite formal differences, the buildings under analysis have essential similarities, while being set apart by many years. The MAM Museum of Modern Art and the Museum of Tomorrow were built seventy years apart. In the background, on the surrounding hills, we are attracted by the charming colour of the landscape of favelas.

\section{CONCLUSIONS AND DESIGN GUIDELINES}

Rio de Janeiro is Brazil's second-largest city. The yearly world-famous carnival, the residents' fascination with football, the beaches of Copacabana, the statue of Christ the Redeemer or Sugarloaf Mountain, the everpresent colour and the culture of the locals visible in the life of the city, as well as the varied architectural styles-are just some of the many of Rio's hallmarks. Corruption, high crime rates or the problems that plague the favelas-are its dark sides. Architecture can affect society and aid in stimulating its activity. The objective of the 'Athenaeum of the World Architecture '20' architectural design competition ${ }^{14,}, 15$ was to design an Athenaeum building that is to be a location devoted to the subject of architecture-to link the architecture of the past and the future, to inspire visitors to discover architecture in ways they have not done so before. The project is to be sited in Rio de Janeiro, which was declared the World Capital of Architecture for 2020. It is the first year of a new initiative by the UNESCO and the International Union of Architects. The objective of this project is to initiate international discussion and attract the attention of the wider community to those contemporary problems that can be solved by architectural and urban planning solutions. The organisers of the competition, when referring to changing trends in architecture, decided that architects no longer design 'just buildings', but ecosystems. Sustainable, energyefficient and socially responsible architecture-are mottoes that should progressively become the standard in design. The Athenaeum design is to combine these ideas, accounting for both place-based historical context, an exceptional site (ocean coast) and an answer to the competition's question: to reference the architecture of the past, the present and to suggest an architecture of the future. This place should inspire both people who are professionally tied to architecture or civil engineering and the wider community that has no ties to these fields. The Master's diploma design by a third-year, second-cycle student of the Architecture and Urban Planning course is an answer to this question. The design was prepared at the Institute of Urban Design of the Faculty of Architecture of the Cracow University of Technology. The author is inż. arch. Maja 
zarówno ludzi związanych zawodowo z architekturą lub budownictwem, jak i szersze grono osób niezwiązanych z tą tematyką. Odpowiedzią na zadanie konkursowe jest projekt dyplomowy magisterski studentki 3 roku studiów II stopnia na kierunku architektura i Urbanistyka. Projekt został wykonany w Instytucie Projektowania Urbanistycznego Wydziału Architektury Politechniki Krakowskiej. Autorką projektu jest inż. arch. Maja Leszczyńska, promotorem - prof. dr hab. inż. arch. Magdalena Jagiełło-Kowalczyk, współpromotorem - dr inż. arch. Bogdan Siedlecki.

\section{PRZYPISY}

https://s3.amazonaws.com/competitions-uni/0/25/Download/team 212019-02-25T15-36-000000.pdf, (dostęp: 08.04.2019)

${ }^{2}$ https://en.oxforddictionaries.com/definition/athenaeum (dostęp: 4.04.2019) 3 https://www.collinsdictionary.com/dictionary/english/athenaeum (dostep: 4.04.2019

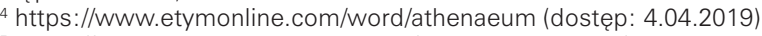

${ }^{5}$ https://www.athenaeumclub.co.uk, (dostęp: 8.04.2019)

https:/www archdaily com/106367/ad-classics-the-atheneum-richard-meier-partners-architects (dostęp 8.04.2019)

7 https://www.worldatlas.com/articles/what-are-the-favelas-of-brazil.htm (dostep: 10.04.2019)

$8 \mathrm{http}: / /$ catcomm.org/favela-facts/, (dostep: 10.04.2019)

9 http://g1.globo.com/rio-de-janeiro/noticia/2011/12/maior-favela-do-pais-rocinha-discorda-de-d ados-de-populacao-do-ibge.html, (dostęp: 10.04.2019) ${ }^{10} \mathrm{https}: / / \mathrm{www}$.budowle.pl/budowla/statua-chrystusa-zbawiciela, (dostęp: 10.04.2019)

${ }^{11}$ http://www.rioonwatch.org/?p=39758_(dostęp: 10.04.2019)

12 https://www.hisour.com/es/the-museum-of-modern-art-in-rio-de-janeiro-brazil-6573/, (dostęp: 10.04.2019)

https://calatrava.com/news/reader/museum-of-tomorrow-wins-best-innovative-green-buildi ng-mipim-award.html, (dostęp 10.04.2019)

$14 \mathrm{https}: / / c 0 m p e t i t i o n s$. uni.xyz/athenaeum? fbclid=IwAR3v 3oWd06W PZrczelddLFyje 9Na5tN 9OIRSooaeVWXgfzT68W G5cjE (dostepp: 5.04.2019). 15 https://architectureau.com/articles/rio-de-janeiro-named-world-capital-of-architecture-2020, (dostęp: 5.04.2019).

\section{LITERATURA}

[1] https://s3.amazonaws.com/competitions-uni/0/25/Download/team21201902-25T15-36-00000 0.pdf, dostep: 08.04.2019

[2] https://en.oxforddictionaries.com/definition/athenaeum dostepp: 4.04.2019

[3] https://www.collinsdictionary.com/dictionary/english/athenaeum dostęp: 4.04 .2019

[4] https://www.etymonline.com/word/athenaeum dostep: 4.04.2019

[5] https:// www.athenaeumclub.co.uk, dostep: 8.04.2019

[6] https://www.archdaily.com/106367/ad-classics-the-atheneum-richard-meier-partners-architects (dostęp 8.04.2019)

[8] Beata Malinowska-Petelenz, Krzysztof Ludwin, Magdalena Jagiełto-Kowalczyk red., Brazylia. Potencjat, Wydawnictwo PK, Kraków 2018,

[9] Bogdan Siedlecki, Przemysław Markiewicz, Brazylia. Zagrożenia, Wydawnictwo PK, Kraków 2018,

[10] Maciej Skaza, Mariusz Twardowski, Magdalena Jagiełło-Kowalczyk red., Brazylia. Perspektywy Wydawnictwo PK, Kraków 2019,

[11] https://www.worldatlas.com/articles/what-are-the-favelas-of-brazil.html dostep: 10.04.2019

[12] http://catcomm.org/favela-facts/, dostep: 10.04.2019

[13] http://g1.globo.com/rio-de-janeiro/noticia/2011/12/maior-favela-do-pais-rocinha-discorda-de-d ados-de-populacao-do-ibge.html dostęp: 10.04.2019

[14] https://www.budowle.pl/budowla/statua-chrystusa-zbawiciela, dostęp: 10.04 .2019

[15] http://www.rioonwatch.org/?p=39758, dostep: 10.04 .2019

[16] Antony Radford, Selen Morkoc, Amit Srivastava, Elementy nowoczesnej architektury. Zrozumieć wspótczesne budynki, Wydawnictwo Arkady, Warszawa 2017, s. $12-28$

[17] https://www.hisour.com/es/the-museum-of-modern-art-in-rio-de-janeiro-brazil-6573/, dostepp: 10.04.2019

[18] https://museudoamanha.org.br/ivro/en/Livro_MdA_DIGITAL_INGLES pdf , 10.04.2019

[19] https://www.archdaily.com/785442/museum-of-tomorrow-santiago-calatrava, 10.04.2019

[20] https://calatrava.com/news/reader/museum-of-tomorrow-wins-bestinnovative-green-buildi ng-mipim-award.html, 10.04.2019

[21] https://competitions.uni.xyz/athenaeum?fbclid=IwAR3v 3oWd06W PZrczelddLFyje_9Na5tN 9OIRSooaeWVXgfzT68W_G5cjE dostęp : 5.04.2019. [22] https://architectureau.com/articles/rio-de-janeiro-named-world-capital-of-architecture-2020, dostęp: 5.04.2019.
Leszczyńska, her main supervisor is dr hab. inż. arch. Magdalena Jagiełło-Kowalczyk and her secondary supervisor is dr inż. arch. Bogdan Siedlecki.

\section{ENDNOTES}

https://s3.amazonaws.com/competitions-uni/0/25/Download/ team212019-02-25T15-36-00000 0.pdf (accessed on: 08.04.2019)

2 https://en.oxforddictionaries.com/definition/athenaeum (accessed on: 4.04.2019)

3 https://www.collinsdictionary.com/dictionary/english/athenaeum (accessed on: 4.04.2019)

4 https://www.etymonline.com/word/athenaeum (accessed on: 4.04.2019)

5 https:// www athenaeumclub.co.uk, (accessed on: 8.04.2019) https://www.archdaily.com/106367/ad-classics-the-atheneum-richard-meier-partners-architects (accessed on 8.04.2019)

$7 \mathrm{https}$ ://www.worldatlas.com/articles/what-are-the-favelas-of-brazil.html (accessed on: 10.04.2019)

${ }^{8} \mathrm{http}: / /$ catcomm.org/favela-facts/, (accessed on: 10.04.2019)

9 http://g1.globo.com/rio-de-janeiro/noticia/2011/12/maior-favela-do-pais-rocinha-discorda-de-d ados-de-populacao-do-ibge.html, (accessed on: 10.04.2019)

10 https://www.budowle.pl/budowla/statua-chrystusa-zbawiciela (accessed on: 10.04.2019)

11 http://www.rioonwatch.org/?p=39758, (accessed on: 10.04.2019)

$12 \mathrm{https} / / / \mathrm{ww}$ w.hisour.com/es/the-museum-of-modern-art-in-rio-de-

janeiro-brazil-6573/, (accessed on: 10.04.2019)

$13 \mathrm{https}: / /$ calatrava.com/news/reader/museum-of-tomorrow-wins-best-innovative-green-buildi ng-mipim-award.html, (accessed on 10.04.2019)

${ }^{14} \mathrm{https}$ ://competitions.uni.xyz/athenaeum?fbclid=IWAR3v_3oWd0 6W PZrczelddLFyje 9Na5tN 90IRSooaeVVXgfzT68W G5̄cjE (accessed on: 5.04.2019)

5 https://architectureau.com/articles/rio-de-janeiro-named-world-capital-of-architecture-2020, (accessed on: 5.04.2019).

\section{REFERENCES}

[1] https://s3.amazonaws.com/competitions-uni/0/25/Download/ team212019-02-25T15-36-00000 0.pdf accessed on: 08.04.2019

[2] https://en.oxforddictionaries.com/definition/athenaeum accessed on: 4.04.2019

[3] https://www.collinsdictionary.com/dictionary/english/athenaeum accessed on: 4.04.2019

[4] https://www.etymonline.com/word/athenaeum accessed on 4.04.2019

[5] https://www.athenaeumclub.co.uk, accessed on: 8.04.2019

[6] https://www.archdaily.com/106367/ad-classics-the-atheneum-richard-meier-partners-architects (accessed on: 8.04.2019)

[8] Beata Malinowska-Petelenz, Krzysztof Ludwin, Magdalena Jagiełło-Kowalczyk ed., Brazylia. Potencjał, Wydawnictwo PK, Kraków 2018,

[9] Bogdan Siedlecki, Przemysław Markiewicz, Brazylia. Zagrożenia, Wydawnictwo PK, Kraków 2018

[10] Maciej Skaza, Mariusz Twardowski, Magdalena Jagiełło-Kowalczyk ed., Brazylia. Perspektywy Wydawnictwo PK, Kraków 2019,

[11] https://www.worldatlas.com/articles/what-are-the-favelas-of-brazil.html

Accessed on: 10.042019

[12] http://catcomm.org/favela-facts/, accessed: 10.04.2019

[13] http://g1.globo.com/rio-de-janeiro/noticia/2011/12/maior-favela-do-pais-rocinha-discorda-de-d ados-de-populacao-do-ibge.html accessed on: 10.04.2019

[14] https://www.budowle.pl/budowla/statua-chrystusa-zbawiciela, accessed: 10.04.2019

[15] http://www.rioonwatch.org/?p=39758 accessed on: 10.04.2019 [16]_Antony Radford, Selen Morkoc, Amit Srivastava, Elementy nowoczesnej architektury. Zrozumieć współczesne budynki, Wydawnictwo Arkady, Warszawa 2017, p. 12-28

[17] https://www.hisour.com/es/the-museum-of-modern-art-in-rio-de-janeiro-brazil-6573/, accessed on: 10.04.2019

[18] https://museudoamanha.org.br/livro/en/Livro MdA DIGITAL INGLES.pdf , 10.04.2019

[19] https://www.archdaily.com/785442/museum-of-tomorrow-santiago-calatrava $\perp_{\perp}$ 10.04.2019

[20] https://calatrava.com/news/reader/museum-of-tomorrow-winsbest-innovative-green-buildi ng-mipim-award.html, accessed on: 10.04.2019

[21]https://competitions.uni.xyz/athenaeum?fbclid= IwAR3v 3oWd06W PZrczelddLFyje 9Na5tN 9OIRSooaeVVXgfz T68W G5cjE accessed on: 5.04.2019.

[22] https://architectureau.com/articles/rio-de-janeiro-named-worldcapital-of-architecture-2020, accessed on: 5.04.2019. 

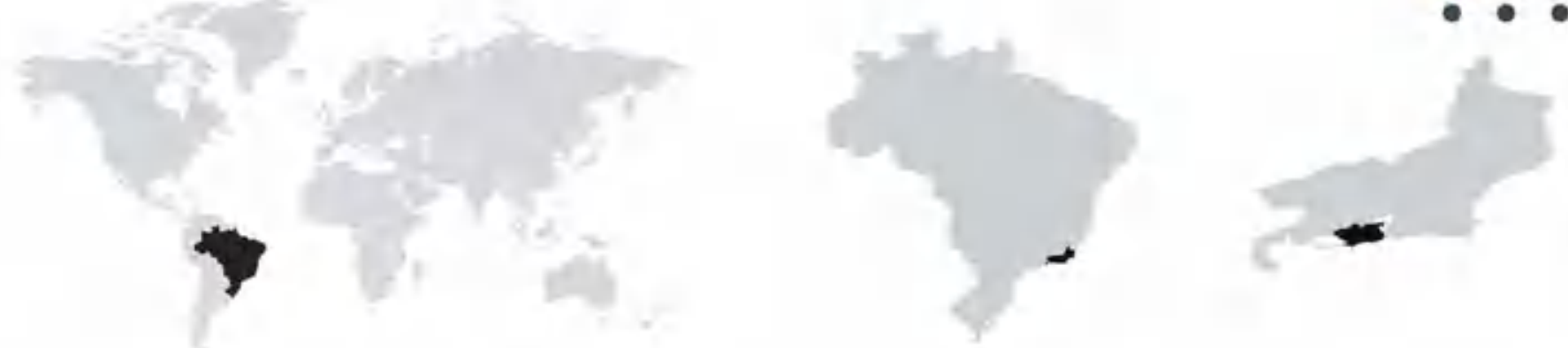

\section{LEGENDA}

\section{AUTOSTRADYIDEOGI EKSPRESOWE}

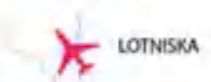

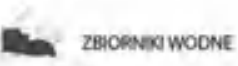

\section{DFOGI ZGORCZE, LOKALNE I DOJAZDOWE}

2. TRANSPORT SZVNOWY (METRO, KOLEL, TRAMWA

(1) 


\section{ATHENAEUM ARCHITEKTURY W RIO DE JANEIRO}

POZIOM WYKSZTAAZCENIA MIESZKANNCOW RIO DE JANEIRO PO 25 ROKU ZYCIA

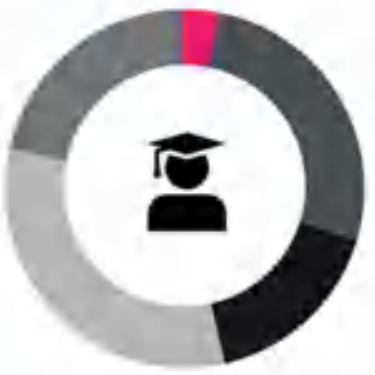

כ]

BRAK / NIEPENE WYKSZTACENIE PODSTAWOWE ORAZANALKABET YZM BRAK/ NEPELNE WYKSZTALCENE POOSTAWOWE - UKONCZONA SZKOLL POOSTAWOWA, NIEUKONCZONA SZKOLA SAEDNIA UKONCZONA 5ZKOLA SAEDNAA BEZ WYZSZEGO WMSSZTAECENAA WVZSZE WYKSZTALCENE

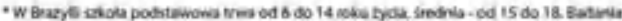
22010

\section{KOMUNIKACIA MIEJSKA RIO DE JANEIRO}

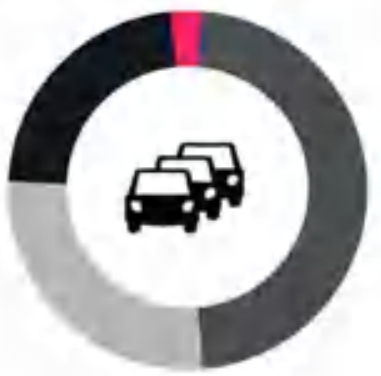

\section{- KOMUNIKACIA SAMOCHODOWA}

- INNE

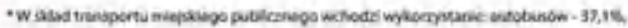

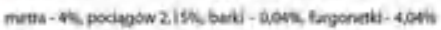

LICZBA MIESZKAŃCOW FAWELIW ZALEŻNOSCI OD CZESCI MIASTA

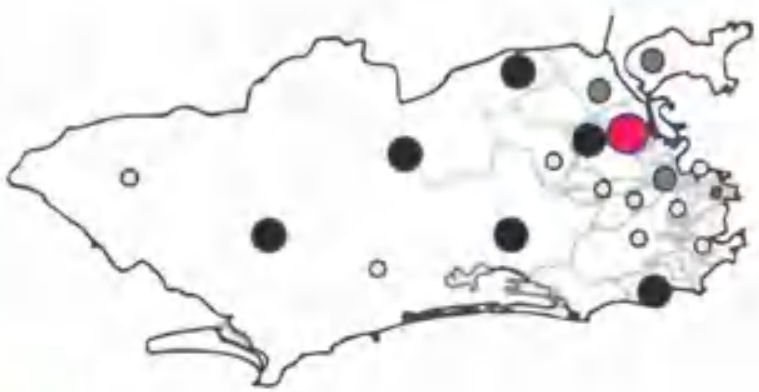

- PCNAD 100000 MIESZKANCOW

- DO50001 Do 100000 mieszakancón

- 0025001 DO sac00 MiESZKANCOW

-.00 10000 DO 25 000 MiEszKANCOW

- do 10000 MiEszKasiców

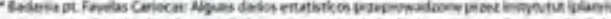

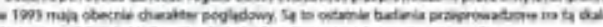

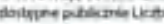

\section{DEMOGRAFIA}

iii

6453700 - LKCZEA MUESZKANCOOW HO DE $1 A$ NE 90 IOFICUALNIE

12070000 - DCZBA MIESZKANCOW PUO OF JANEISO RAZEM Z OBSZA. REM ACR OMERACII I SZACOWANA LKZEA OSOE NIEZARE ISTROWAOMCH

2253.600 - LCZEA TURYSTOW IROCZNE, 2018)

\section{PRACA IWYKSZTAECENIE}

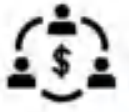

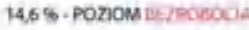

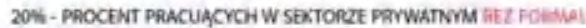
NEGO ZNAMUONIENA

8.43\% * ROOZINY UTRZYMULACE SE $Z$ KWOTY MHE ISZFI NQZ JEDNA PLACA MENAMALNA MIESEECZNIE NA GOSPODARSTWO DOMOWVE.

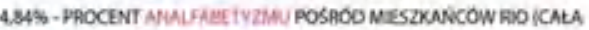
BRAZMUA - 7,4\%, POLSKA - 0,2\%)

213 W PROCENT SPCEECEENSTWA PO 25 ROKU ZVCIA POSIACA WYZSI Wossztancenat.

\section{PROBLEMY}

\section{WYSOKI POZIOM PRZESTEPCZOSC}

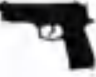

WYSOKA LCZBA ZNEDISI W - OK, 30 CFIAR TYGOONIOWO

HANDEL WAUETTMUN SZCZEGOLNE W FAWELACH MESIECZNIE ZE SPRZEDAZY NASWOTMKOW GANGI UZYSKUIA SZACUNKOWO 1500000005. GANGI STANOMA NILFORMALNA, ALE PHAWDZIWA WLADZE W WEOSZOSO Faweul

HCFUACIA, RO DE JANERO, POOCBNIE JAK I CALA BRAZYULA WTPADA BAROZO ZLE W WYNIKACH BAOAN Z ZEWNATHZ. WOHODZ W SKLAD NA.

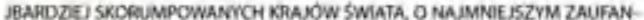
iU SPOLECZENSTWA ITRMNSPARENCY ENTEENATONALS 2018 CORRUPTOWN PERCEPTIONS INDEX).

\section{SRODOWISKOI KATASTROFY}

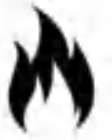

UCZNE POZAGY ZABOWNO LASOW JAKI EUDVNKOW MUN SPLONECOE NASSTARSZEGO MUZUEM I INSTYTUCII NAUNOWE 2 WHEESNIA 2019r. MUZEUM NARCOOWECO W BRAZVUL, SPLONELO $905 \mathrm{~S} 2200$ TVS. EKSPONATow)

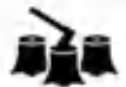

\section{NIEKONTROLOWANE WYINK LASOW}

KATASTROFY ENOLOGICZNE, SPOWODOWMNE PRZEZ ELEON LUDZKEE I KOAUPCIE, PRZVRCADV:

WVMIERANIE RVB I ROSUN PRZEZ ZANIECZYSZCZENIA WOO TOKSYCENYMI SUSSTAWCIMMI IDATA, NAZWA

OGMOMNE SZKOOY SPOWODOWANE PRZEZ NOWAZZE ZANED. BANUA BUDOWLANE, TECHECCZNE ORAZ BPAX INSPEKCE NP. ZAWALENA TAM IDATA NAZWM

FAWELE

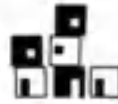

FAWEL FTO OCAOMNA CZESCMUASTA - WWEKSZOSCI NEKONTACLOWANYCH PRZEZ RZAD TERENCW

- 1400000 - UCZBA OSOE MIESZKAIMCYOH W 763 FAWELACH RO DE LANEMO, TO $N Z$ LRS SPOSPDOD MIESZKANVCOW MIASTA.

RUONNSA ORAZ INGRASTRSJKTURA TWORZONE SA PRZEZ MIESZKANCOW W RAMACH SANOWOUL BUDOWLANES, GANGI STANOWMA NHEST MALNA WLADZE W WIEXSZOSCI FAWEU PRAD JEST POWSZECHIIE KRADZZONYZ SEO MUASTA, PODOENE LAKINNE MEOIA KTORE DA SE TAM DOPROW. AOZC

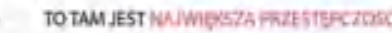

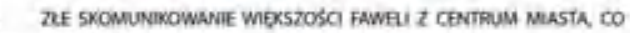
WPEYWA NA IOH WMKLUCZENAE.

- CORAZ WĘCE FAWEU PEZEESZTALCA SE W CENTRA ZVCIA NOCNEGO I KULTUPOWEGO NEKTOPE FAWEUE SA GETINE I ULCZNIE OOWIEDZANE PRZEZ TUFYSTów

OAGLANCZNE ROTRASTANIE SIE FAWEI STANE SE CORAZ CZESCIE PRZEOMIOTEM ANALIZ AMCHTEKTONACZNO-SOCICLOGICZNYCHE MIMO WELU PAOULEMOW I WAD COFAZ CZESCE W POZY T WWMM SWETLE. 


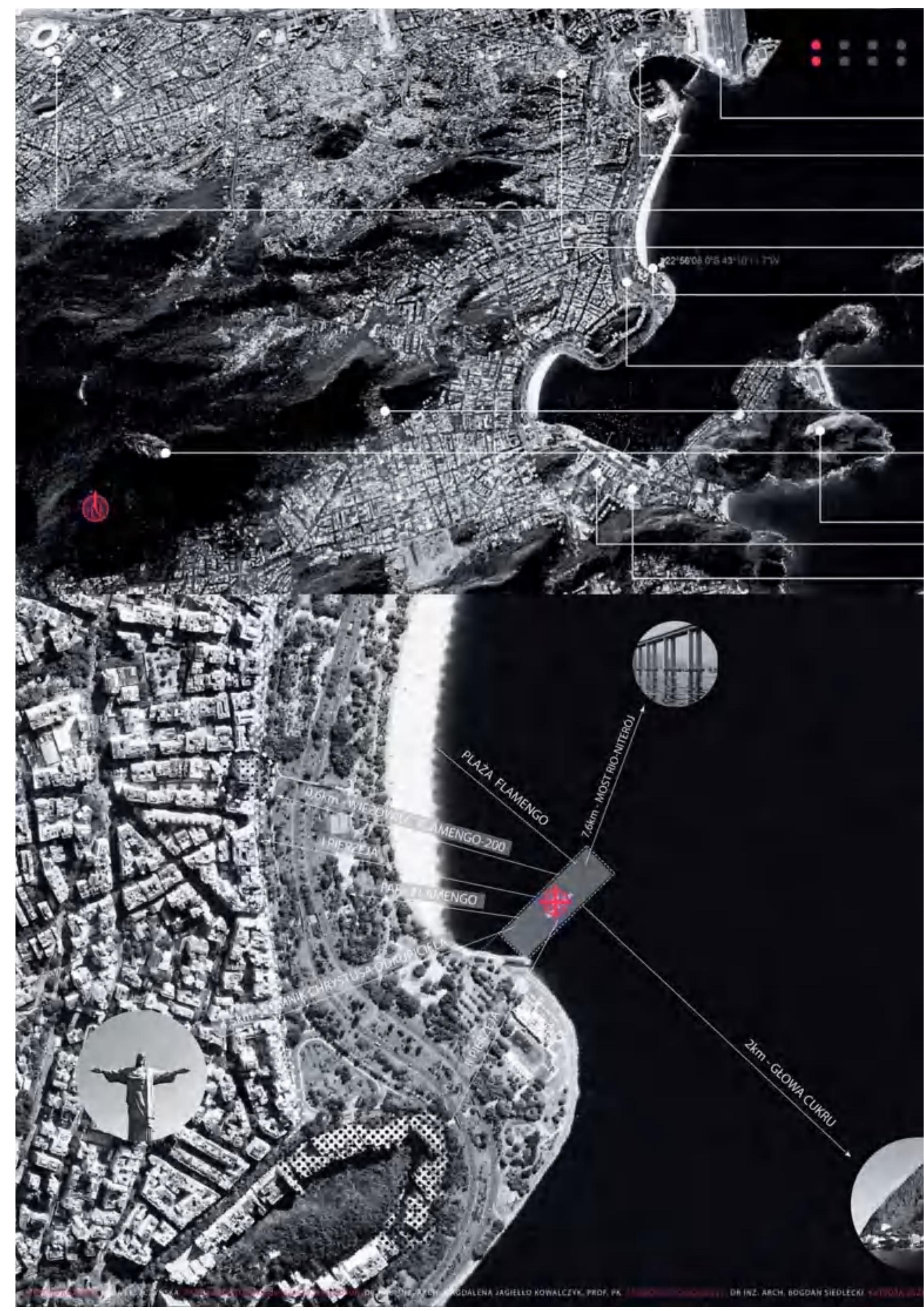




\section{ATHENAEUM ARCHITEKTURY W RIO DE JANEIRO}

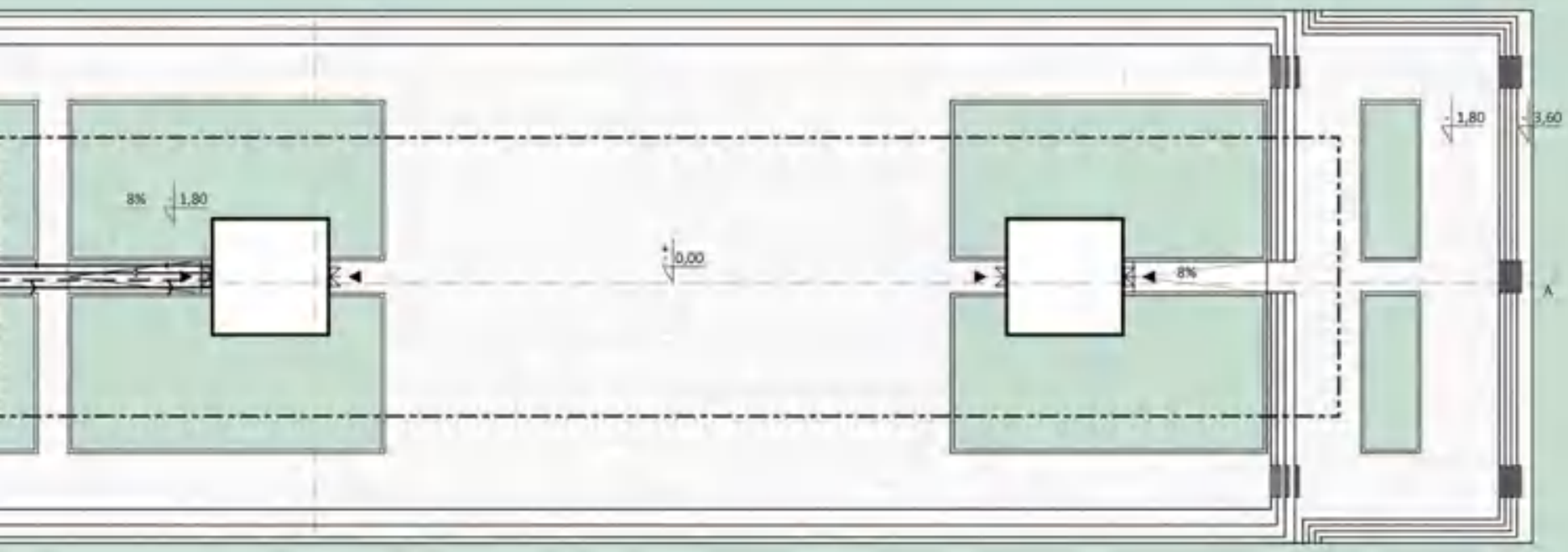

m

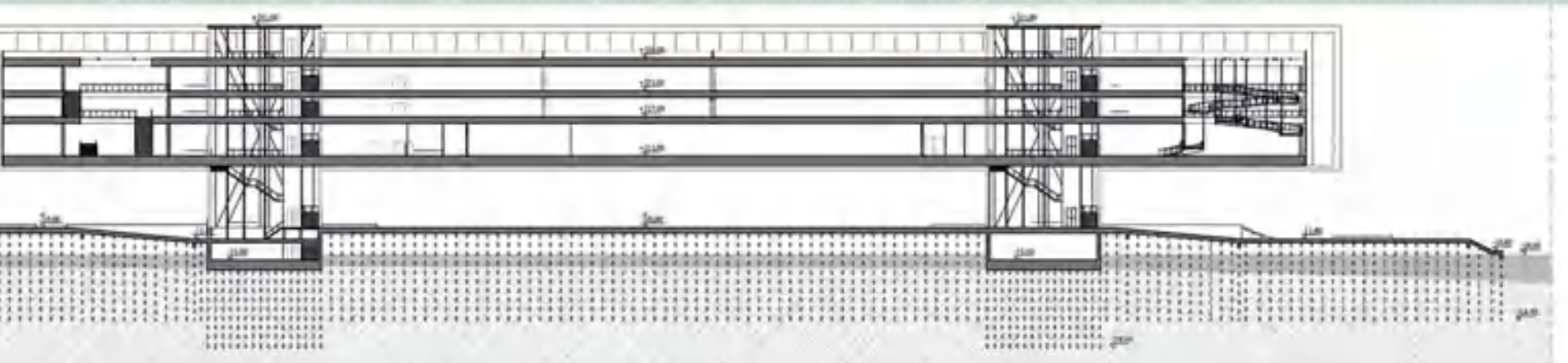

\section{RAMPA}

LOKALNA INSPIRACJA: MUZEUM SZTUKI WSPÖLCZESNEJ - OSCAR NIEMEYER, NITEROI

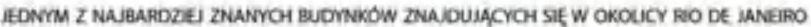
JEST MUZEUM SZTUKJ WSPCRCZESNEI W NITEROL . .ECO NIEZWMKLE OHARAXTERYSTVCZNA RAMPA PEUNI ROLE, DAOGI DO WESCIA GLOWNEGO ORAZ DAOGI WOOKOWE, UMOZLWWWACE POOZWLANE KRANOBRAZU OTACZAJACEGO MUZEUM.

RAMGM ZNAJDUJACA SIE W ATRENAEUM NAWLAZUIE DO NIEJ ORAZ POZWALA NA OGLADANIE EKSPOZYCI Z ROZNYCH POZIOMOW.

\section{PODNIESIENIE BRYKY, WOLNY PARTER}

LOKALNA INSPIRACJA: MUZEUM SZTUKI - LINA BO BARDI, SĀO PAULO

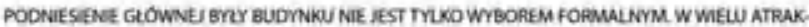
CINKCH LOKALZACIACH KONSTRUKCIA OEIEKTU OD POZIOMU PARTERU „ZAEEERA CENWY WDOK NA TO, CO WCZESNIE BRO WDOCZNE PO DFUGIE STRONIE, DODMTKOWO, DZENO POD. NEESIENIU BRRY OQEKT UZYSKUJ] DODATKOWA PRZESTRZEN PUBUCZNA, W KTOREJ MOZNA SIE SOHACNCC PAZED DESZCZEM ORAZ CAGANIZOWAC ROZNE WTOARZDNIA I WYSTAWE

W WTPAOKU ATHERLAEUM POONESIENIE BUDNRU BRO JEDNA Z RLJWAZNIEJSZYOH IDEI, ZE WZGLEOU NA WSPANIALY KRANOERAZ OTACZAACCY BUDMNEK.
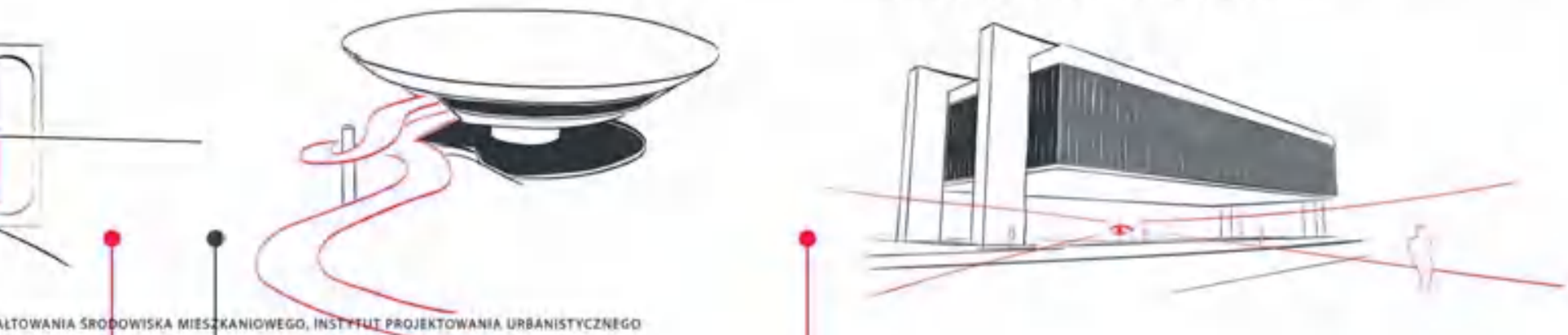

ZESTAWIENIE POWIERZCHNI

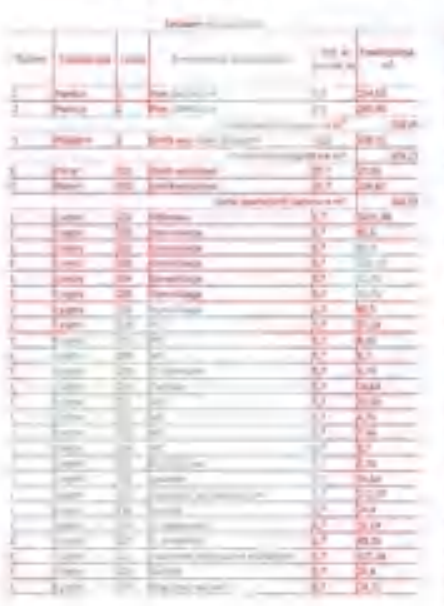

RZUT, POZIOM 0

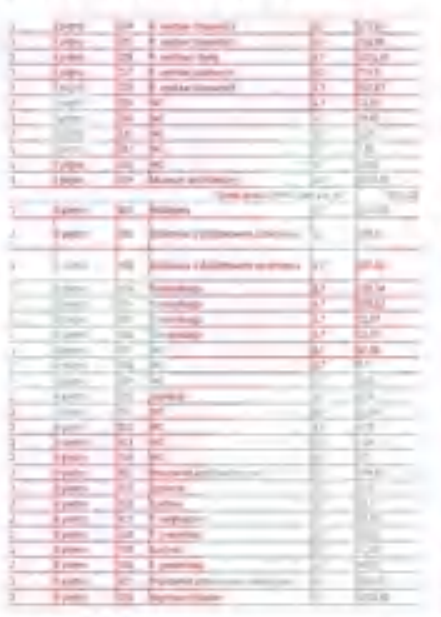

DETAL, SKALA $1: 20$

t3.

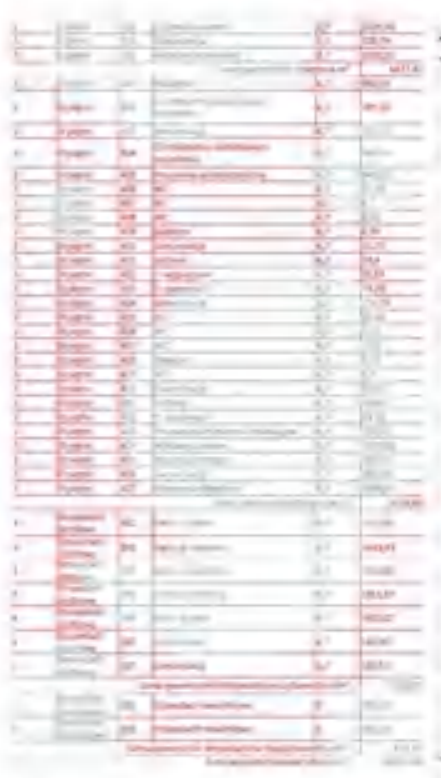

(1)

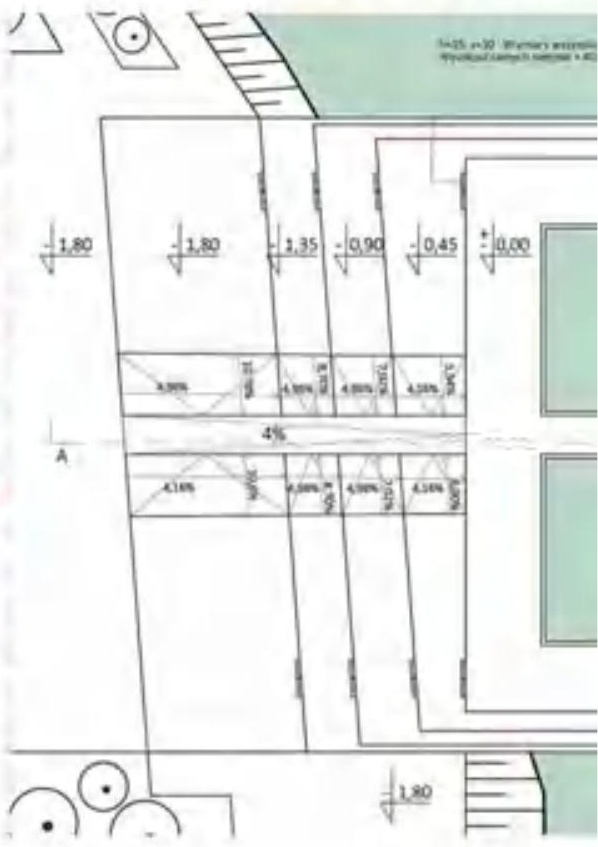

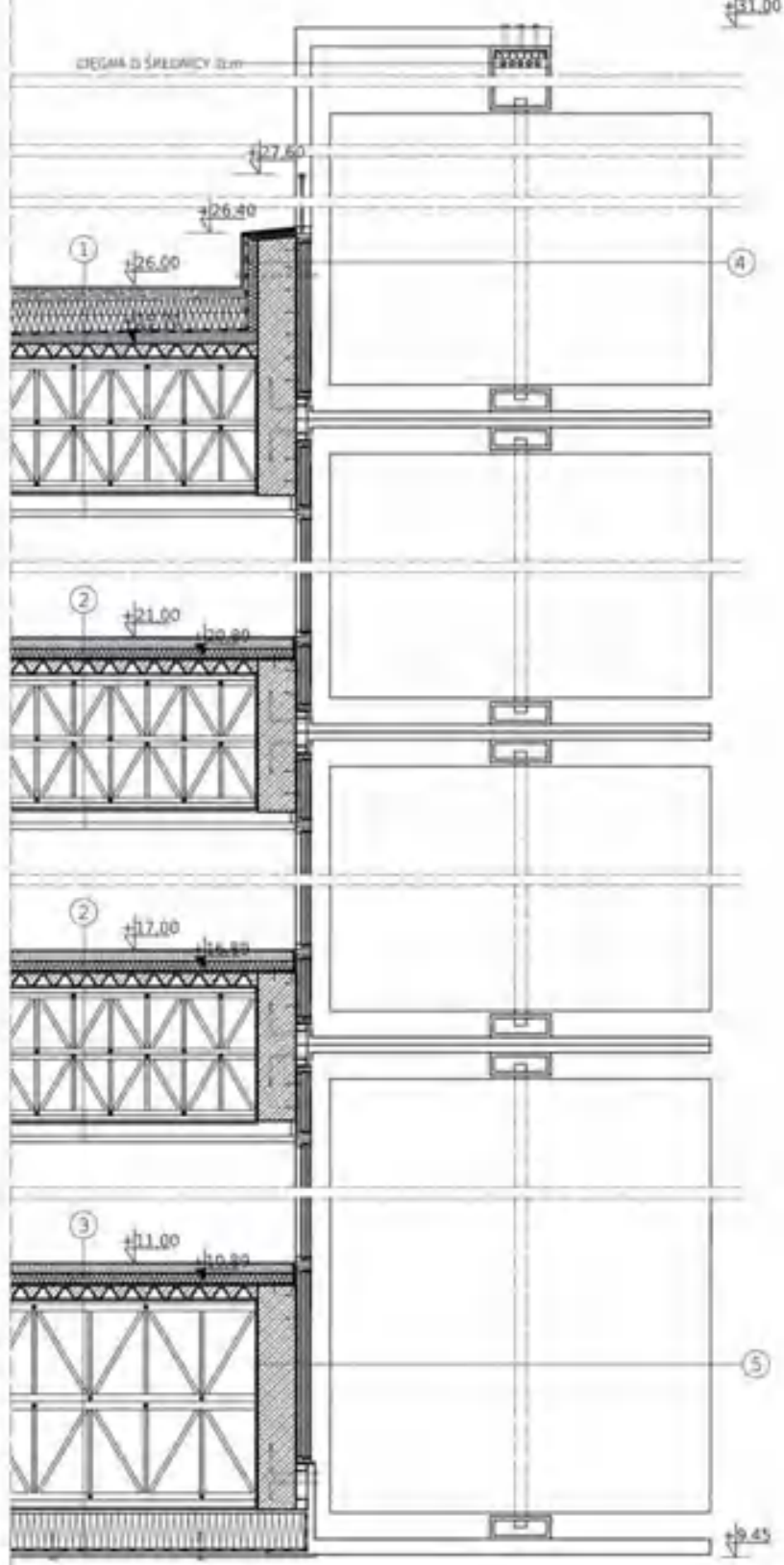

\begin{tabular}{|c|c|c|}
\hline $1.5 \mathrm{~cm}$ & REYTR BETOWOWE & \\
\hline \multirow[t]{2}{*}{$4.12 \mathrm{~cm}$} & ZWIR & \\
\hline & WEOEDUKA RLTRUJACA & \\
\hline \multirow[t]{2}{*}{$30 \mathrm{~cm}$} & POUSTYRES EKSTRUDOWANY & त \\
\hline & 2XPAPA TERMOZGRZZEWALISA & $D$ \\
\hline $622 \mathrm{~cm}$ & WAASTWA SPNOKOWA Z LEKOEGO ALTDKU & 5 \\
\hline $7 \mathrm{~mm}$ & BLACHA TRAFEZOWA Z WYLFWA (2-6CM) & $D$ \\
\hline$\overline{n e m}$ & 2 RZEDO KRATOWNIC PRZESTRZENWWCH & $\rightarrow$ \\
\hline \multirow[t]{2}{*}{$12 \mathrm{~cm}$} & SUFIT POOWIESZANY & - \\
\hline & 2) & $\circ$ \\
\hline $\mathrm{iem}$ & FYTR EETONOWE & \\
\hline $4 \mathrm{~cm}$ & WrEEWEA & \\
\hline
\end{tabular}

$4 \mathrm{~cm}$ STrAOTLAY

FCW BLACHA THAPEZOWAZ WVLEWKG (2.6CM)

$72 \mathrm{~cm}$ 2 RZZGOY KRATOWWEC PRZESTRZZNWTCH

$12 \mathrm{~cm}$ Sulit poOWESZavr

\begin{tabular}{|c|c|}
\hline $1 \mathrm{~cm}$ & FerTE BETONOWE \\
\hline $4 \mathrm{~cm}$ & WREWKA \\
\hline $4 \mathrm{~cm}$ & STrAOMAS \\
\hline $7 \mathrm{~cm}$ & BLACHA TRAFEZOWA Z WVIEWKA (2-6CM) \\
\hline $110 \mathrm{~cm}$ & 2 RZEEY KRATOWWOC PRZESTRZENWWYCH \\
\hline $20 \mathrm{~cm}$ & STYROANGS \\
\hline $1.2 \mathrm{~cm}$ & 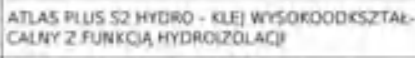 \\
\hline$a .6 \mathrm{~cm}$ & 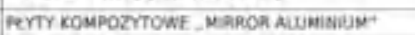 \\
\hline
\end{tabular}

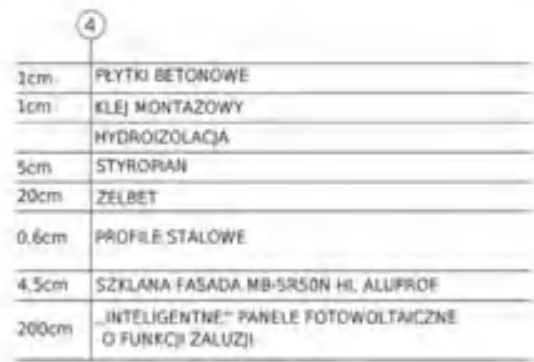

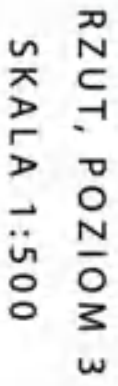

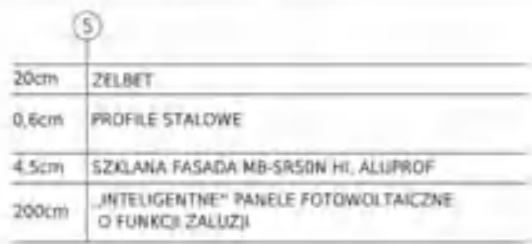

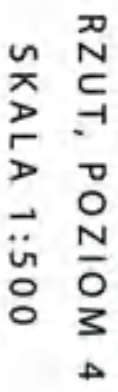




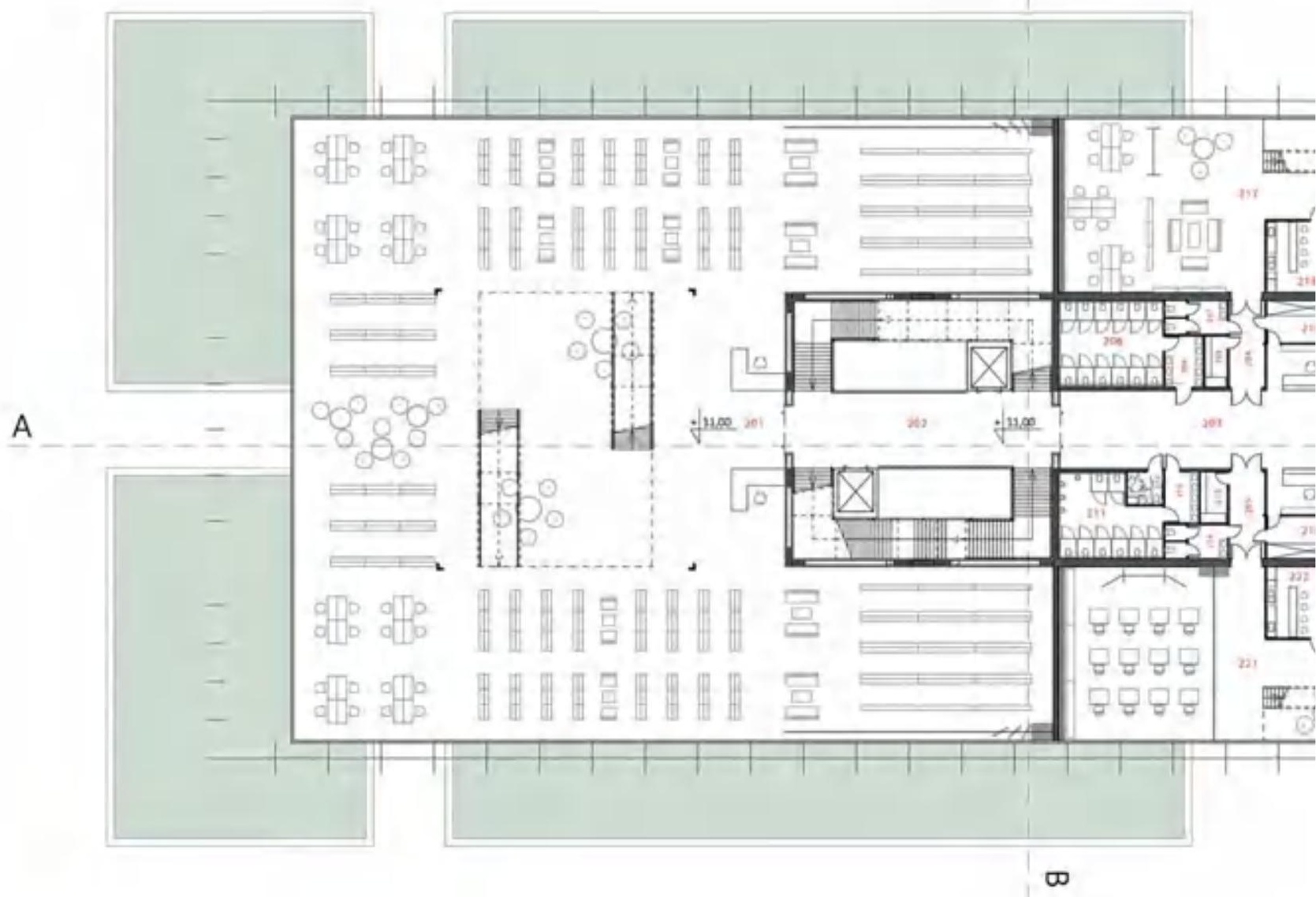

ELEWACJA PÓtNOCNA, SKALA 1:200

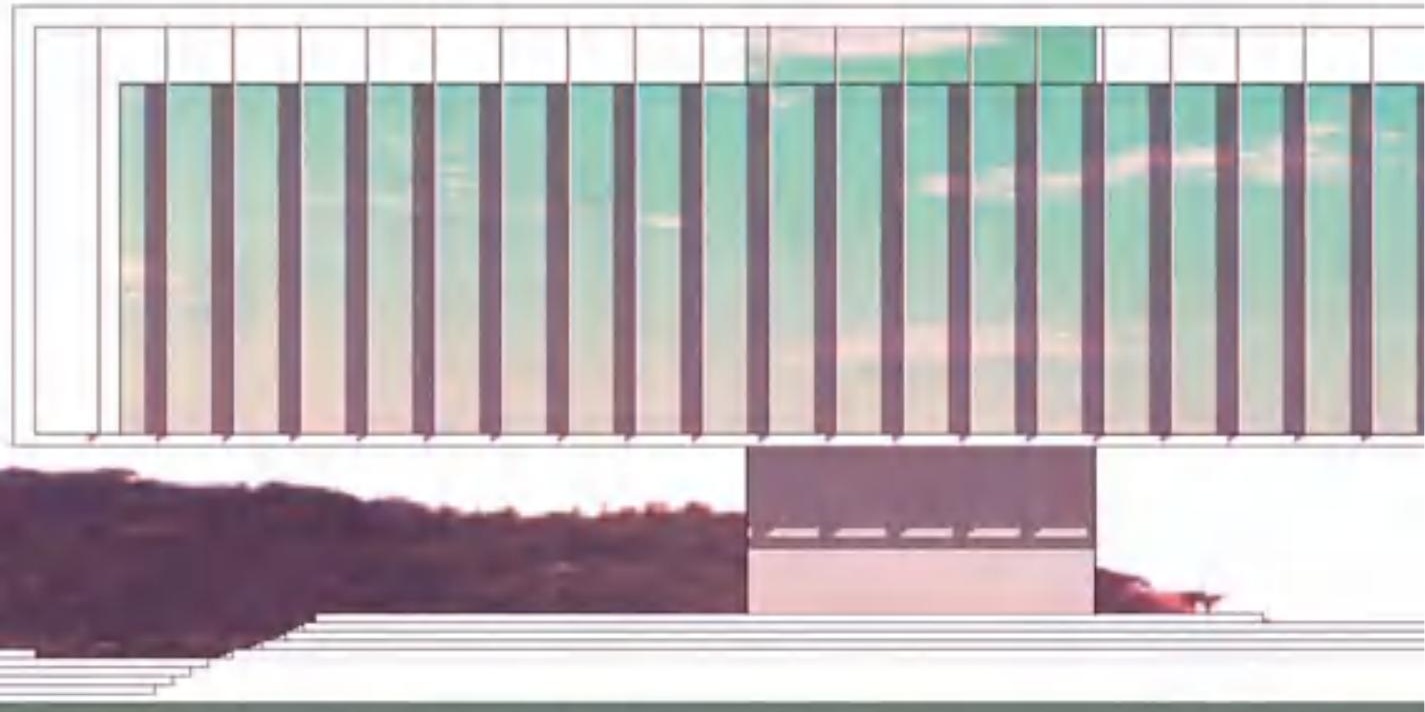




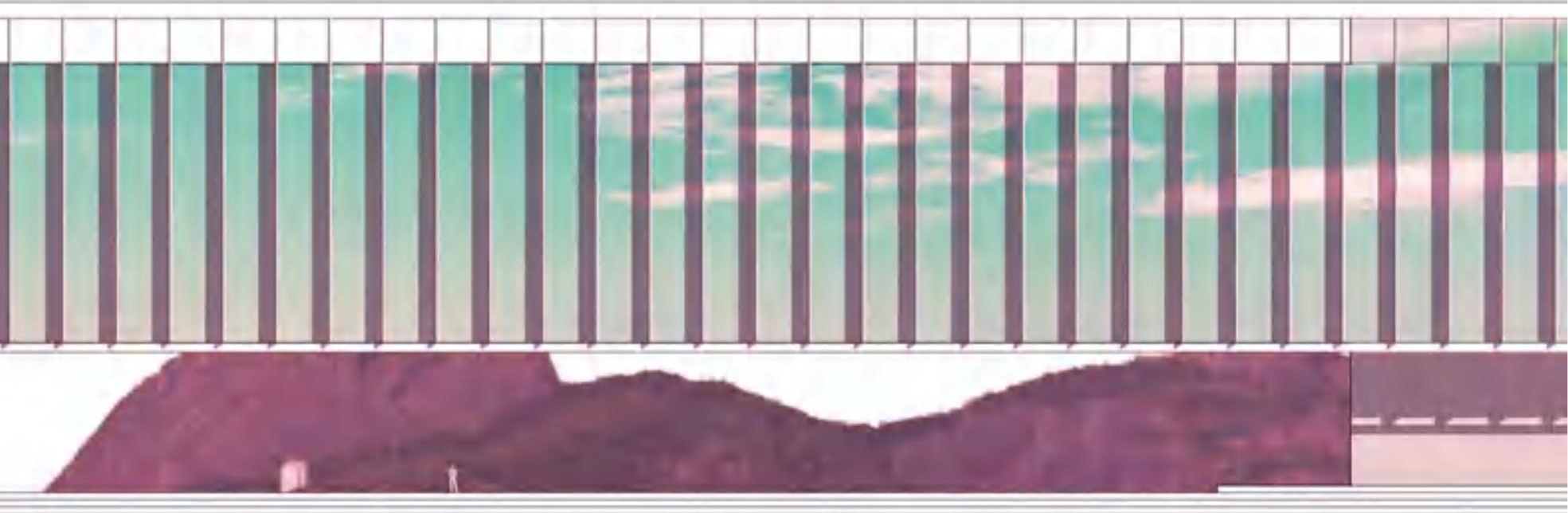




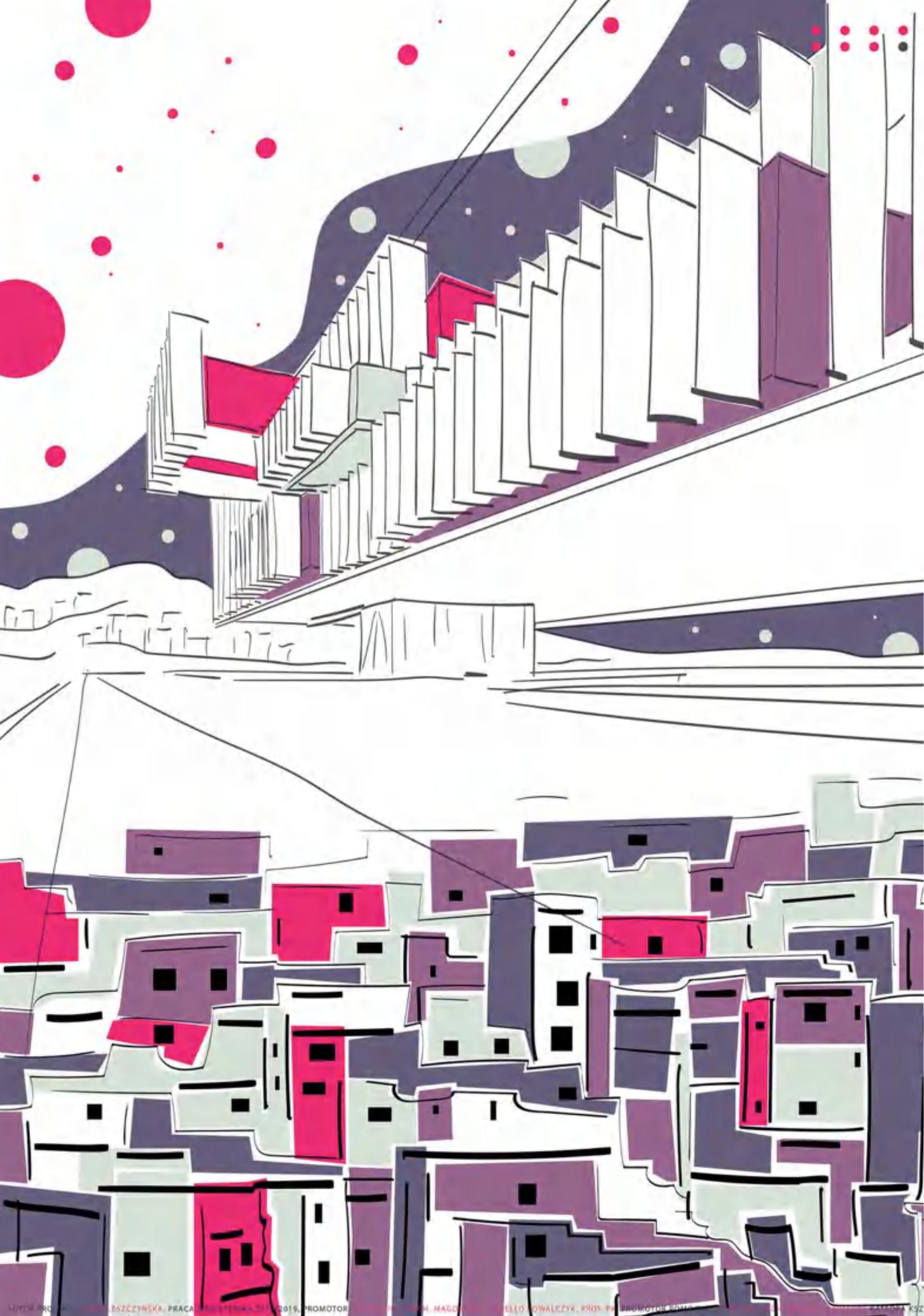





\section{ATHENAEUM ARCHITEKTURY W RIO DE JANEIRO}

$\mathrm{ZIOMO}$

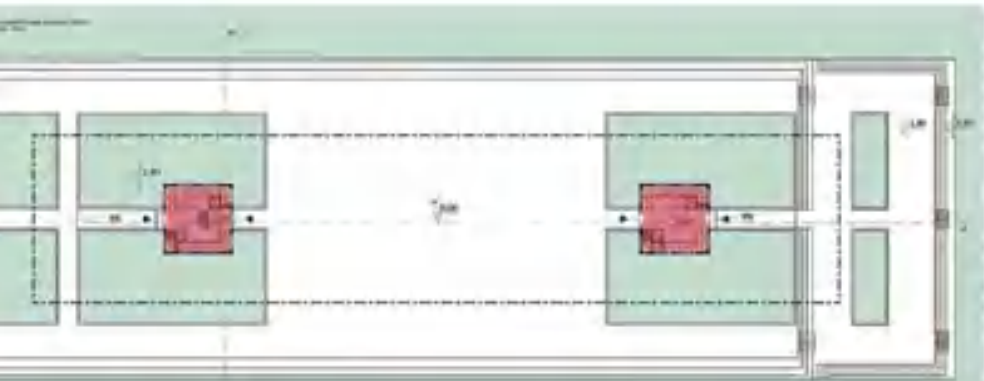

KOMUNIKACJA,

EWAKUACJA

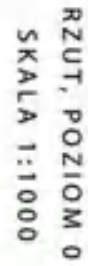

$\sim \stackrel{\pi}{N}$

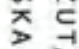

$>$

$\vec{*}$ 운

$\ddot{\circ} \frac{0}{\circ}$

BIBLIOTEKA (STREFA

NIERUCHOMA)

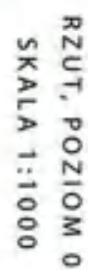

STREFA TECHNICZNA

I MAGAZYNOWA

STREFA SANITARNA
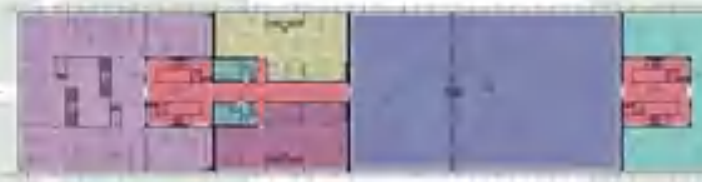

CZĘŚĆ MUZEALNA, STA $₫ A$ (NIERUCHOMA)

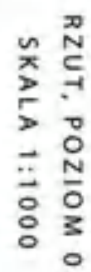

PRACOWNIE

ARCHITEKTONICZNE (STREFY RUCHOME)

PRACOWNIE

EDUKACYJNO-ARTYSTYCZNE

(STREFY RUCHOME)

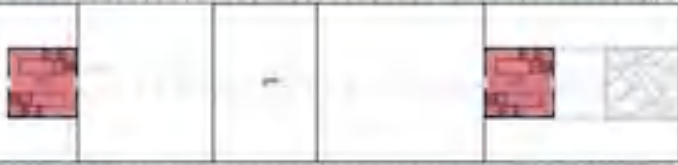

T

.

$>$ 음

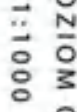

WYSTAWY CZASOWE

(STREFY RUCHOME)

HODNIA, SKALA 1:200

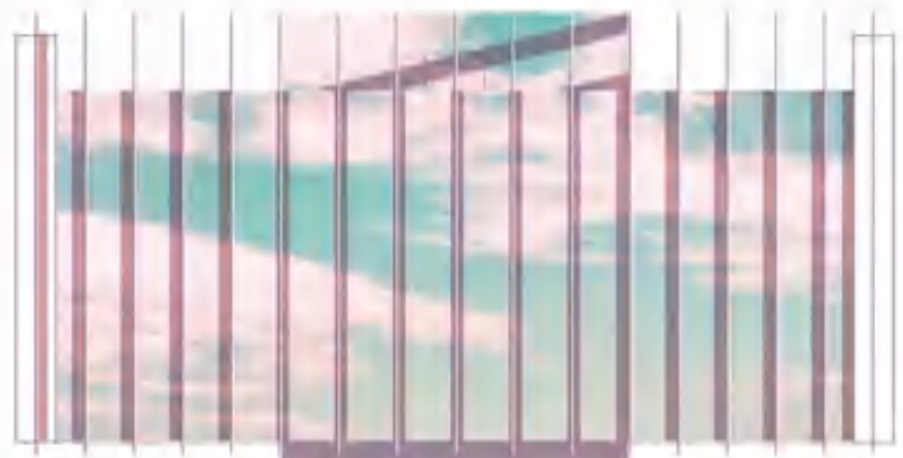




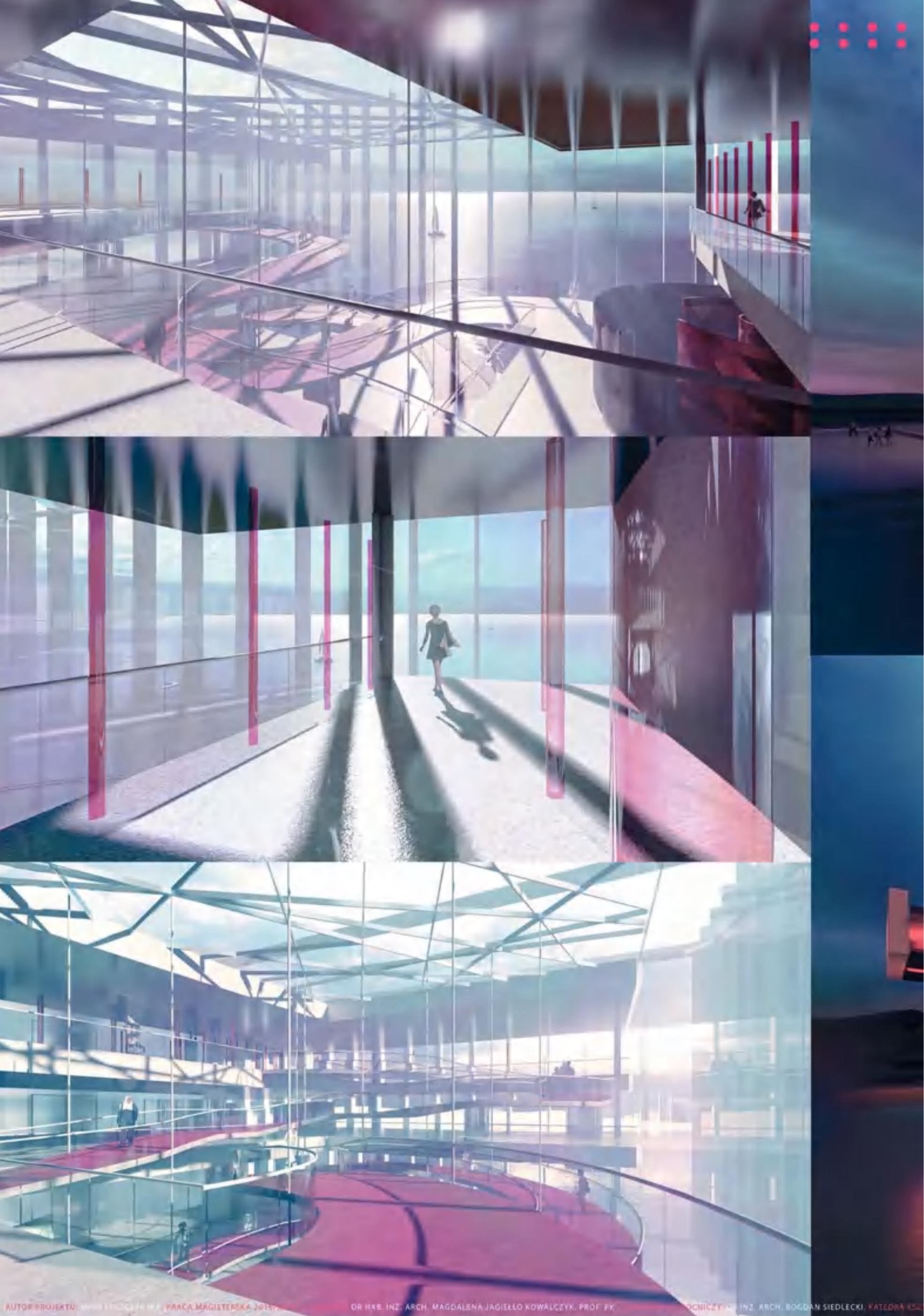


UM ARY'HITEKTURY W RIO DE JANEIRO

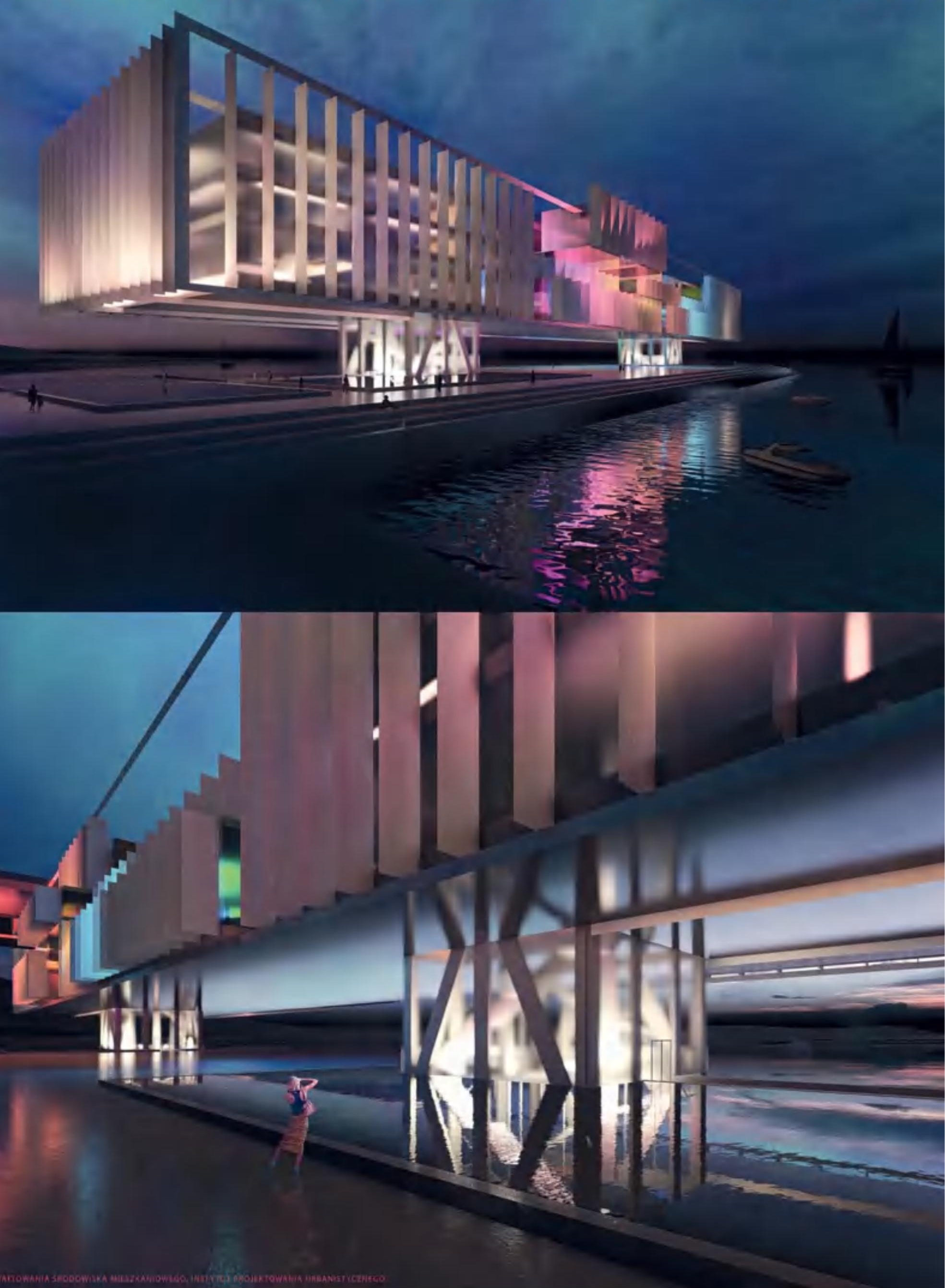




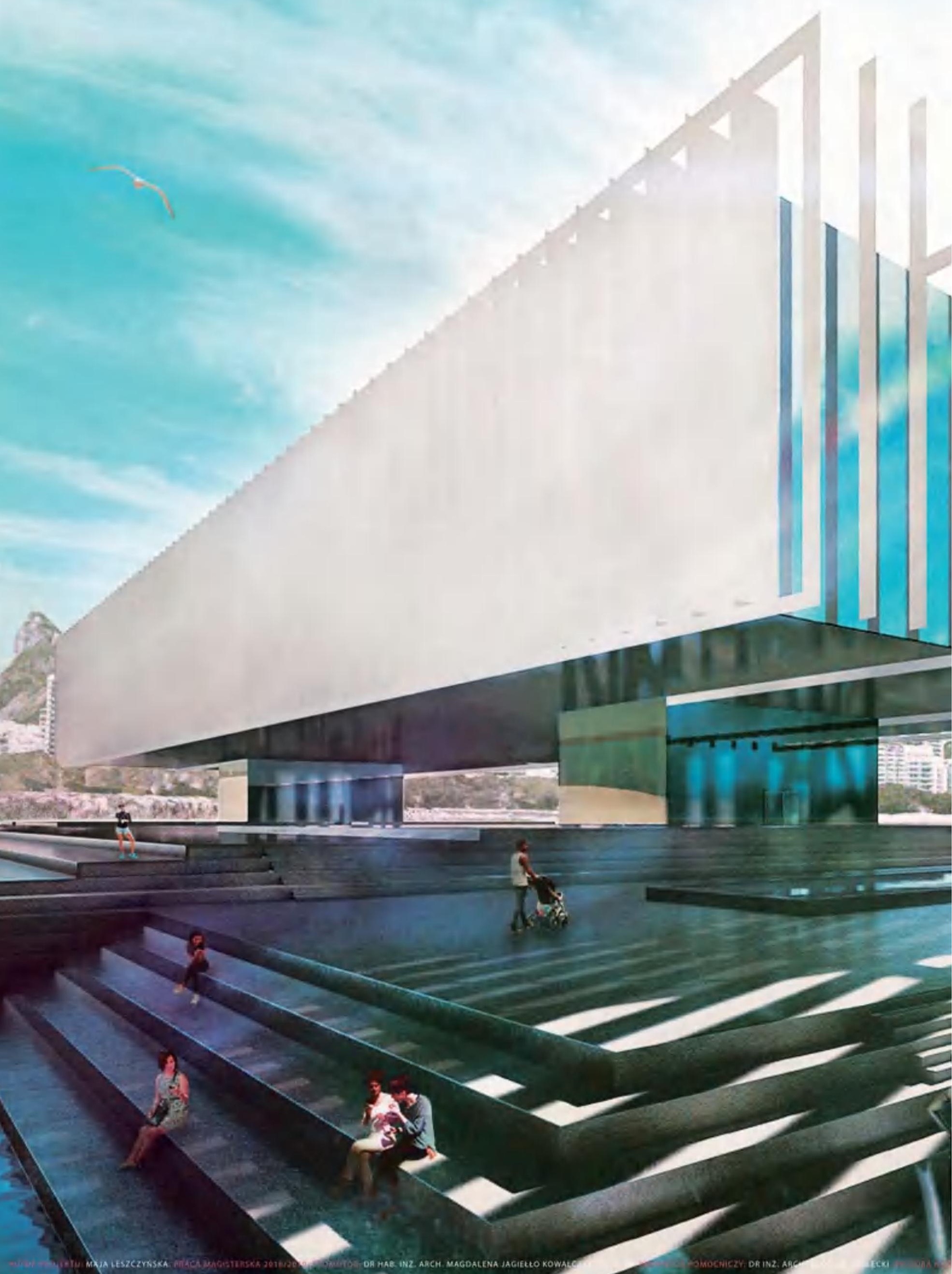


